\title{
PRESERVATION AND PROTECTION OF NATIVE BIODIVERISTY IN THE GUADALUPE NIPOMO DUNES COMPLEX
}

\author{
A Thesis \\ presented to \\ the Faculty of California Polytechnic State University, \\ San Luis Obispo
}

In Partial Fulfillment of the Requirements for the Degree Masters of Science in Biological Sciences

by

Lindsey M. Whitaker

August 2016 
(C) 2016

Lindsey M. Whitaker

ALL RIGHTS RESERVED 


\section{COMMITTEE MEMBERSHIP}

TITLE: $\quad$ Preservation and Protection of Native

Biodiversity in the Guadalupe Nipomo Dunes

Complex

AUTHOR: $\quad$ Lindsey M. Whitaker

DATE SUBMITTED: August 2016

COMMITTEE CHAIR: $\quad$ Dr. Scott Steinmaus Ph.D.

Horticulture \& Crop Science Department Chair

COMMITEE MEMBER: Jon Hall M.S.

Restoration Manager, The Land Conservancy of

San Luis Obispo County

COMMITTEE MEMBER: $\quad$ Dr. Matt Ritter Ph.D.

Professor of Biological Sciences 


\begin{abstract}
Preservation and Protection of Native Biodiversity in the Guadalupe Nipomo Dunes Complex

Lindsey M. Whitaker
\end{abstract}

The Guadalupe Nipomo Dunes Complex (GNDC) is located within the California Floristic Province, a biodiversity hotspot characterized by high rates of endemism and exceptional loss of habitat. In 1980, the US Fish and Wildlife Service described the GNDC as, "the most unique and fragile ecosystem in the State of California," and ranked it first on a list of 49 habitat areas needing state protection. It is the largest coastal dune area in California and it is one of the last remaining, relatively intact ecosystems of its type and size in the western United States. The growing recognition of species decline and the limited number of dollars allocated to conservation and restoration have led to development of new conservation planning software and conservation strategies. Marxan and Zonation were selected for this project due to their worldwide acceptance in biodiversity conservation planning as well as their specialization in identifying priority zones for conservation. This document describes the unique use of conservation planning software to select areas for resource allocation. It outlines the process of selecting conservation targets, the habitats and species important to overall health of an ecosystem, by using the expert involvement approach. Most importantly, this document outlines areas of high biodiversity that will later be used to allocate resources for the preservation and protection of biodiversity within the Guadalupe Nipomo Dunes Complex. Introduced species are the second-leading cause (after habitat degradation/loss), causing or 
contributing to the decline in species abundance and diversity. Ehrharta calycina Smith has become highly invasive in the coastal dune communities of Central and Southern California and currently holds a "high" CAL-IPC inventory rating, defined as a species with severe ecological impacts on physical processes, plant and animal communities and vegetation structure as well as reproductive biology and other attributes conducive to moderate to high rates of dispersal and establishment. Ehrharta calycina is a prolific seeder and stores its seeds annually in the soil, collecting a substantial seedbank. Little is known about E.calycina outside its native range, as its invasion into California coastal ecosystem is fairly recent. A field experiment in the Guadalupe Nipomo Dunes Complex assessed the contribution of seeds originating from the seedbank as compared to seeds from above ground either dropping from maternal plants or blown in from outside the plots to the establishment of new E. calycina cover. After a nine month perios, new $E$. calycina cover from both sources was not significantly different. Visible coverage of $E$. calycina began 77 days (November 24, 2015) after plot installation. After nine months of surveying, coverage reached $19 \%$ in the Seedbank Present treatment and $21 \%$ in the Seedbank Absent treatment. There was no significant effect associated with the slope and aspect of the experimental locations. This experiment will aid in management of this invasive species by educating land managers to focus on preventing current seed production of established individuals as those sources of seed were as important as those originating in the seedbank. Stimulating germination of seeds from the seedbank with a concomitant management strategy such as herbicide application or physical removal will likely be the most effective methods for dealing with seeds in the seedbank. 


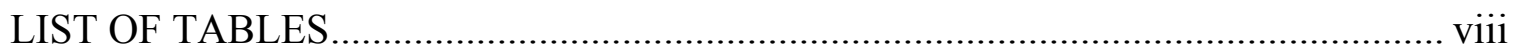

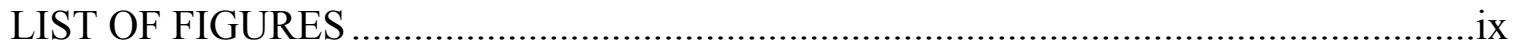

CHAPTER 1: IMPROVING CONSERVATION PLANNING METHODS FOR THE

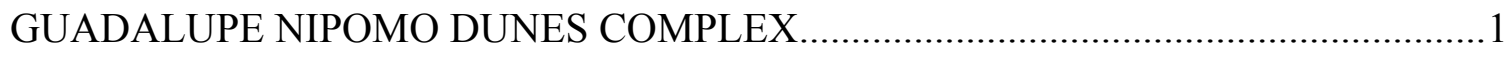

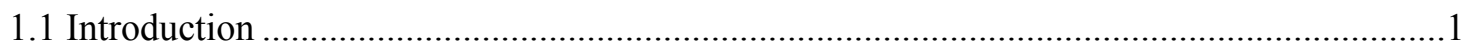

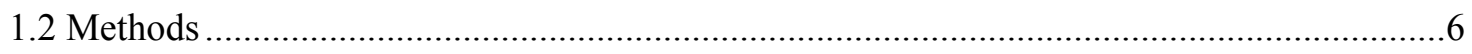

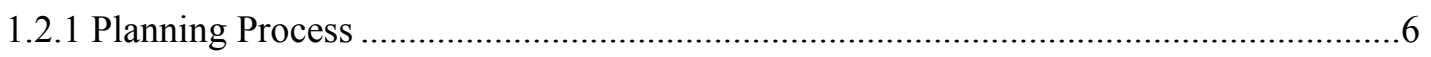

1.2.2 Conservation Planning Software .............................................................................14

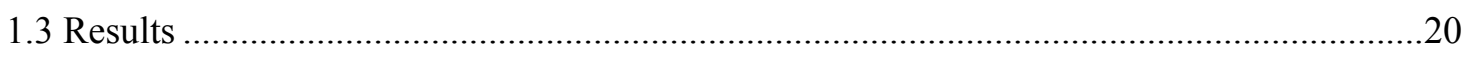

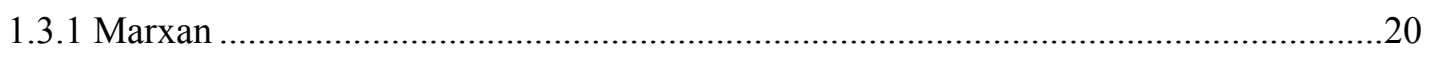

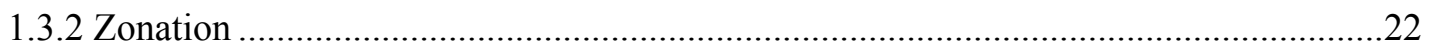

1.3.3 Comparison of Top 11\% of Selected Area ……………………………………......22

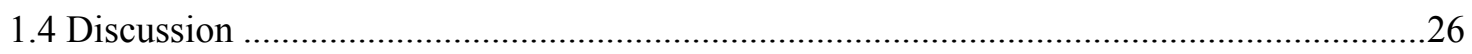

CHAPTER 2: ADVANCEMENTS IN THE UNDERSTANDING OF INVASIVE SPECIES, EHRHARTA CALYCINA, PERENNIAL VELDTGRASS IN CALIFORNIA'S

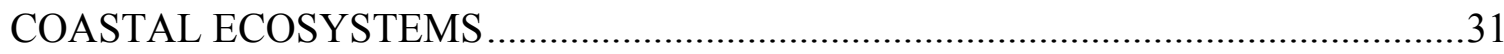

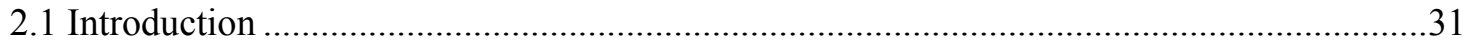

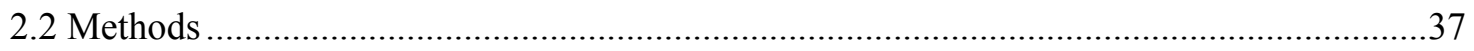

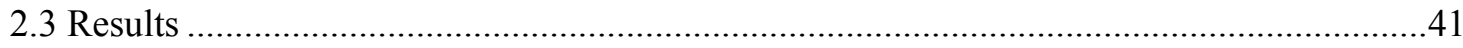

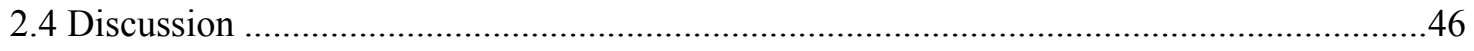

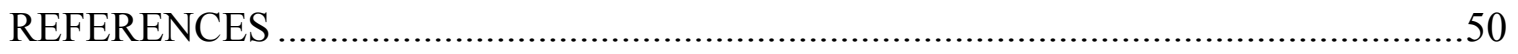

APPENDICES 


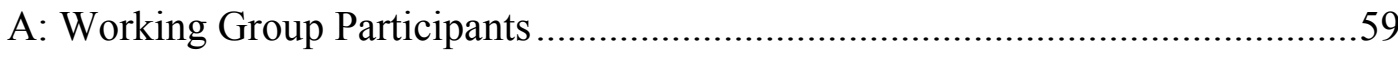

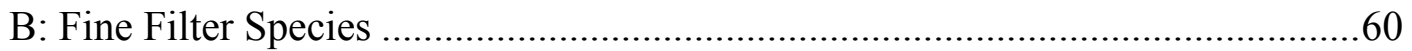




\section{LIST OF TABLES}

Table

Page

1. Rarity Rankings for the Coarse Filter. Rarity rankings were given to each

habitat type based on the amount of habitat present in the GNDC.

2. Coarse Filter Rankings. Coarse Filter vegetation types chosen and ranked by working groups according to rarity. *Southern non-native grassland has not been ground-truthed for possible native grassland so it was chosen to have a high ranking for possible rarity. 12

3. Habitat Types Represented in Selected Areas. ...........................................................24 


\section{LIST OF FIGURES}

Figure

Page

1. Study Area. Guadalupe Nipomo Dunes Complex located on the Central

Coast of California in San Luis Obispo and Santa Barbara Counties. 3

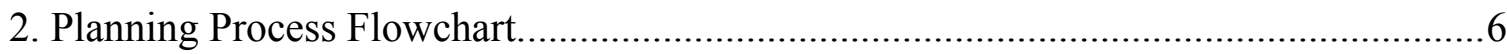

3. Habitat Types. Habitat types not included in the region are converted agricultural lands and were not included in analysis. .11

4. Marxan Output. Marxan's output for the list of conservation targets. Only the top $50 \%$ of the total area of the complex is displayed with the areas in red beginning of the highest priority for conservation. Secondary areas include orange/yellow-labeled areas. .21

5. Zonation Output. Zonation calculates the output by evaluating cells based on conservation targets ranks compared to the neighboring cells slowly eliminating lower ranked areas. Areas in red are the areas of highest conservation value with orange and yellow areas ranked slightly lower. .23

6. Top Areas by Habitat. The top 21\% of total area selected by A) Marxan and B) Zonation broken down by habitat type. All habitat types were represented in each of the models.

7. Comparison of Top $11 \%$ of Chosen Area. The top ranked areas in each model (Zonation in green and Marxan in purple) and the overlapping areas in both models (red). Overlapping area is 618.84 acres or $32 \%$ of the entire complex. .25 8. Selected Area, Oso Flaco Lake. Oso Flaco Lake was selected by both of the models as an important area for resource allocation because its diversity 
of habitats.

9. Ehrharta calycina in the Guadalupe Nipomo Dunes Complex. A) E.calycina

can be seen invading open areas of coastal dune scrub habitat (pale grass

surrounding evergreen coastal dune flora). B) E.calycina uses tillering to

increase its diameter and protect itself against the difficult environment of

the coastal dunes.

10. Site Locations. Map of the chosen sites along the southern border of the

Oceano State Parks property (property line highlighted in blue). North of sites

is the Land Conservancy of the San Luis Obispo County's Black Lake Ecological

Area. 1,000 feet is indicated on the scale in the bottom left corner.

11. Plot Descriptions. A) Seedbank Present plot with only debris and vegetation

removed with no alteration of the seedbank. B) Seedbank Absent plot with

seedbank physically removed with general kitchen hand sifter. C) Visual

demonstration of how seedbank was removed from Seedbank Absent plots.

D) The presence/absence transect grid used to measure presence and absence in

each of the plots

41

12. Percent Coverage of Ehrharta calycina in both Seedbank Present and Seedbank

Absent treatments. Treatment type was not significant over time

$(\mathrm{F}$ Test $=9.117, \mathrm{p}$ value $=0.1650)$

13. Percent Coverage by Slope. Plots of both treatment types were analyzed

for possible relationship. Blue diamonds represent Seedbank Present plots and

black diamonds represent Seedbank Absent plots.

14. Percent Coverage by Aspect. Percent cover plotted for both treatment 
types. Blue diamonds represent Seedbank Present plots and black diamonds represent Seedbank Absent plots.

15. Aspect of Plots. Range of aspects for all plots, Seedbank Present and Seedbank Absent. Blue lines represent Seedbank Present plots and black ines represent Seedbank Absent plots. 


\section{CHAPTER 1}

\section{IMPROVING CONSERVATION PLANNING METHODS FOR THE GUADALUPE NIPOMO DUNES COMPLEX}

\subsection{Introduction}

Over 7500 vertebrates, 4000 invertebrate species and 10,500 species of plants from around the world are on the 2014 International Union for Conservation of Nature (IUCN) Red List of Threatened Species. This is double the number of species listed in 2000 (IUCN, 2015). In California alone, 52 species of animals and 218 species of plants are listed threatened, endangered or rare under the California Endangered Species Act (CESA, 2015). The major reasons for the decrease of biodiversity is due to conversion and fragmentation of habitats, introduction of nonnative species, pollution, direct exploitation of species, the disruption of natural ecological processes, industrial-scale agriculture and forestry, climate change and overall human associated disturbances of the Earth's ecosystems (Cardinale, Duffy, \& Gonzalez, 2012; Fiedler, 1986; Hilton-Taylor, 2000; Wilcove, Rothstein, Dubow, Phillips, \& Losos, 1998). The decrease in species reduces the efficiency of ecological communities to capture biologically essential resources, produce biomass, decompose and recycle essential nutrients (Cardinale et al., 2012). With the overwhelming evidence supporting the significant loss of the species and their importance to overall ecosystem health, efforts to conserve biodiversity have arrived at the forefront of the conservationist's attention (Cardinale et al., 2012; Franklin, 1993; Groves et al., 2002; Harte, 2001; Myers et al., 2000; Pimm, Russell, Gittleman, \& Brooks, 1995). Intact ecosystems which support large numbers of species and are a 
significant risk of loss of habitat are being selected to help preserve and promote the protection of biodiversity.

The Guadalupe Nipomo Dunes Complex (GNDC) is located within the California Floristic Province, a biodiversity hotspot characterized by high rates of endemism and exceptional loss of habitat (Myers et al., 2000). In 1980, the US Fish and Wildlife Service described the GNDC as, "the most unique and fragile ecosystem in the State of California," and ranked it first on a list of 49 habitat areas needing state protection. It is the largest coastal dune area in California and it is one of the last remaining relatively intact ecosystems of its type and size in the western United States (U.S. Fish and Wildlife Service, 2000).

The GNDC is located within San Luis Obispo and Santa Barbara Counties and spans the coast from Pismo Beach in the north to Point Sal in the south (Figure 1). The GNDC encompasses approximately 17,000 acres and stretches along 18 miles of coastline (California Department and Fish Game, 1976). It supports an abundant diversity of plant and animal species, many of which can only be found in this area. Examples of major habitat communities found within the GNDC include coastal dune scrub, riparian wetland, coastal dune swale and foredune mat (California Department and Fish Game, 1976; U.S. Fish and Wildlife Service, 2000). 


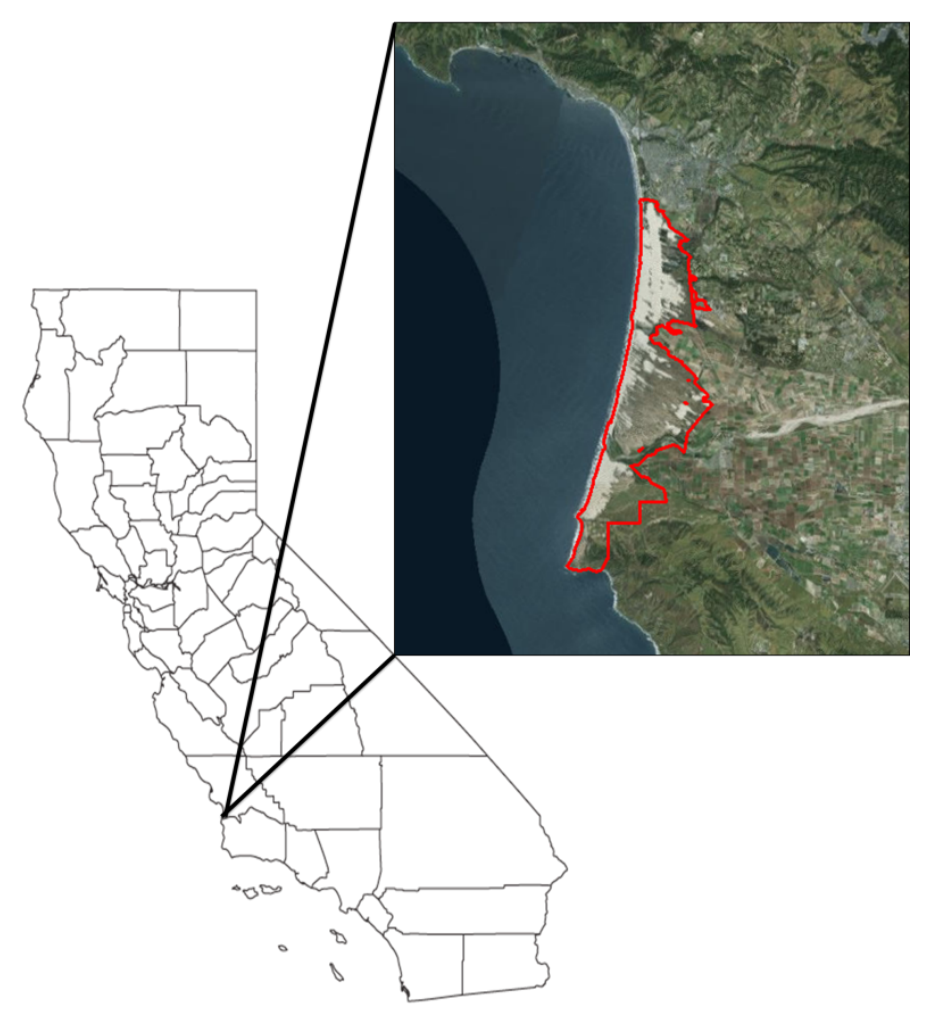

Figure 1: Study Area. Guadalupe Nipomo Dunes Complex located on the Central Coast of California in San Luis Obispo and Santa Barbara Counties.

Historically, humans have had a negative impact on native dune vegetation that can be traced back to Mexican Land Grants of 1835 and the introduction of cattle grazing and nonnative plants to the region. Later, resource and energy extraction as well as off-road vehicle use further degraded habitats within the GNDC (California Department and Fish Game, 1976). Invasive plant species are considered the biggest threat to the GNDC's unique habitats. Most significantly, African veldt grass (Ehrharta calycina Smith) and European beachgrass (Ammophila arenaria (L.) Link) have been rapidly invading important specialized habitats within the GNDC and changing the ecosystem dramatically (The Land Conservatory of San Luis Obispo County, 2003). These species 
were brought to the coastal dunes by humans in order to support agriculture, recreation and urbanization of the California coast (Lamson-Scribner, 1895; Love, 1963; Pickart, 1997). The introduction of these species has decreased native biodiversity by disrupting dune stabilization process (Gilbertson, Schwenninger, Kemp, \& Rhodes, 1999). Whether it be increasing stabilization along the shore (Ammophilia arenaria) or resetting dune making processes inland with foraging (Ehrharta calycina), these species have tampered with delicate ecosystem processes that native species depend on (D'Antonio \& Vitousek, 1992; Gilbertson et al., 1999). According to a 1976 California Department of Fish and Game report, the coastal dune habitat was relatively free of nonnative vegetation; however recent reports estimate a high percent of dune habitats are heavily infested with invasive grasses (The Land Conservatory of San Luis Obispo County, 2003, 2011).

Restoration and conservation of a large unique ecosystem such as the GNDC is expensive and current methods addressing encroachment of invasive species often occurs after invasions have already done major impact to an ecosystem (Groves et al., 2002). New conservation planning methods are now focused on preventive conservation which will allow for more cost-effective and efficient management of native ecosystems (Groves et al., 2002; C. R. Margules \& Pressey, 2000). Ecosystems such as the Guadalupe Nipomo Dunes Complex represent an excellent candidate for the prioritization and promotion of biodiversity through the use of conservation planning software.

Conservation planning software streamlines the planning process and creates costeffective and unbiased priority areas for the conservation and restoration of important 
species and habitats (C. R. Margules \& Pressey, 2000; C. Margules \& Sarkar, 2007; Wilcove et al., 1998). The effectiveness of these conservation strategies derive from their ability to use limited resources to achieve conservation goals, their defensibility and flexibility in the face of competing land uses and their accountability in allowing decisions to be critically reviewed (C. R. Margules \& Pressey, 2000). Using a more modern approach to conservation planning with the use of software will allow managers to be proactive rather than reactive (Groves et al., 2002; C. R. Margules \& Pressey, 2000).

The GNDC offers a unique opportunity to use conservation planning software in a new and relevant way. The GNDC is already predominately under public ownership or conservation easement and has been recognized as an important biodiversity haven (California Department and Fish Game, 1976; The Land Conservatory of San Luis Obispo County, 2003; U.S. Fish and Wildlife Service, 2000). Most applications of conservation prioritization software are used to dictate land acquisition or formation of reserve systems (Airamé et al., 2003; Fernandes et al., 2005; Kremen et al., 2008). This new application would use conservation planning software to select areas of most biodiversity and dictate which areas within the GNDC would be managed for protection and promotion of that biodiversity.

This document describes the unique use of conservation planning software to select areas for resource allocation. It outlines the process of selecting conservation targets, the habitats and species important to overall health of an ecosystem, (Pressey et al., 2003) by 
using the expert involvement approach. It also discusses the strengths of the software applications selected to be used. Most importantly, this document outlines areas of high biodiversity that will later be used to allocate resources for the preservation and protection of biodiversity within the Guadalupe Nipomo Dunes Complex.

\subsection{Methods}

\subsubsection{Planning Process}

The ultimate goal of this research is to identify areas within the GNDC that represent habitat for a large diversity of species. Details of each step of the process will be explained in the following sections (Figure 2). A panel of expert biologists and ecologists and the known databases of the species and vegetation types were assembled. Experts then filtered the data to identify and delineate the general habitats supporting plants and animals (Coarse Filter) and classified the species that would most benefit from conservation efforts (Fine Filter). Experts evaluated each species based on the habitat necessary for its survival and the current stressors present on selected species.

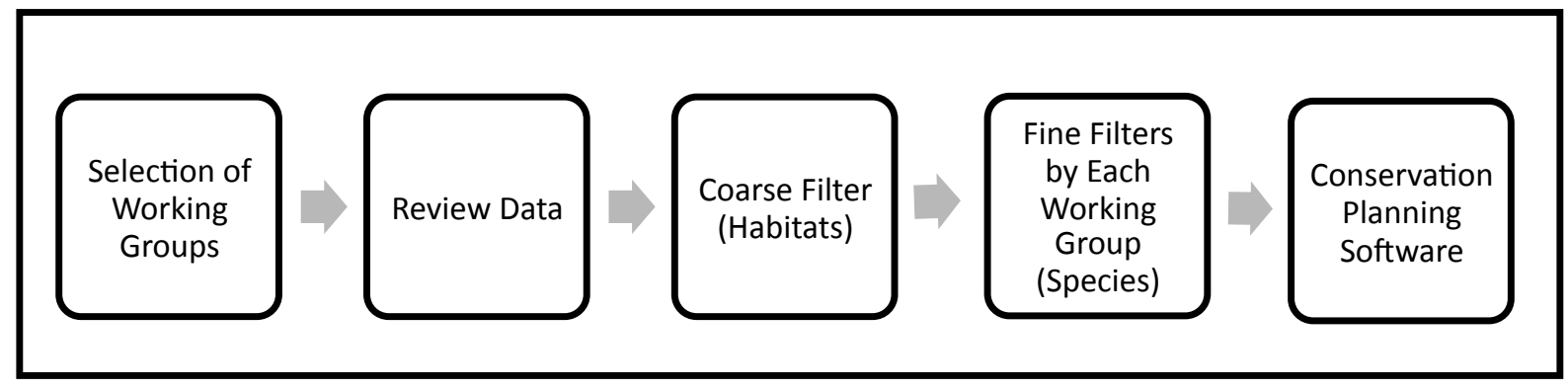

Figure 2: Planning Process Flowchart. 
A database of ecological and biological information (species occurrences, vegetation cover, boundaries, etc.) created by the Land Conservancy of the San Luis Obispo County (LCSLO) was used by the expert working groups for consideration of conservation targets. The database is a compilation of numerous datasets from stakeholders throughout the GNDC. Datasets incorporated in the compilation included species occurrences, vegetation cover, roads, complex and property boundaries, and water resources. Data was limited in some areas of the GNDC, specifically in the southern portion due in large part to the lack of funding for biological surveys and private land ownership. Data collected varied between properties. Some stakeholders within the GNDC chose to be excluded from the conservation planning process and were therefore not included within this study.

The Expert Involvement approach to conservation planning integrates data collected in the field, computer software and expert knowledge (Cowling, Pressey, Rouget, \& Lombard, 2003). Experts were chosen based on their long-term professional dedication to the coastal dune habitats and the species that depend on them. This includes professors with PhDs in their taxonomic group as well as biologists with other degrees who have spent their career studying this area. Stakeholders were also included in the planning process because they will be implementing the final output of the models. Experts were organized into the following working groups: mammals, birds, rare plants, invertebrates, lichens and reptiles and amphibians (A full list of each working groups participants can be found in Appendix A). Working groups approved data and species locality as well as created a ranking system used for each chosen conservation target. 
Conservation targets are explicit targets for the proportion of habitat needed for a species or vegetation community to sufficiently persist and thrive in perpetuity (Lu, Zhi-yun, Wei-hua, \& Chun-quan, 2014). Both vegetation communities (Coarse Filter) and species' necessary habitat (Fine Filter) are essential conservation target for the evaluation of biodiversity (Game et al., 2008; Moilanen et al., 2014). Each conservation target was vetted by one or more working group and represents the knowledge currently available either through recorded data or expert observation.

The conservation planning process begins with a coarse filter of generalized vegetation/habitat types in an effort to represent a diversity of vegetation types. Each expert working group then added additional fine filters to more accurately include the biodiversity. Additional conservation targets were chosen as fine filter layers if a species did not have their necessary habitat accurately represented in the rankings of the coarse filter.

The fundamental goals of the coarse filter are to organize and rank the habitat types to characterize habitat rarity and importance to biodiversity. The conservation targets selected in the coarse filter allow for a more general look at the vegetation cover which aided in the selection of conservation targets of the fine filter.

In order to best represent the biodiversity spanning the entire GNDC, the complex was spilt into three regions, or landscape units: North, Central and South. These regions represent natural breaks in specialized habitat types and have been cited as so in the 
literature (Holland, Keil, \& Oyler, 1995). This regional splitting ensured all chosen conservation targets were represented across their entire range. For example, coastal dune swale was abundant in the northern region allowing more stability. The southern region does not have many areas of coastal dune swale making those small areas very vulnerable to possible threats. This allows us to bolsters resilience in the event of major habitat loss, rapid climate change or other disturbances (Baosc, 2012).

Coarse filter conservation targets were created based on rarity rankings given to each habitat set by the working groups (Table 1). The rankings were chosen based on the rarity of the habitat type and the number of species dependent on it for survival. Each rank was paired with a, "Suitable Amount of Habitat," necessary for persistence of that habitat type. These conservation targets included broad categories of the vegetation and were organized based on dominant species and habitat function (Figure 2). This process produced 21 different ranked vegetation types (Table 2). 
Table 1: Rarity Rankings for the Coarse Filter. Rarity rankings were given to each habitat type based on the amount of habitat present in the GNDC.

\begin{tabular}{|c|l|c|}
\hline Rank & \multicolumn{1}{|c|}{ Rank Description } & $\begin{array}{c}\text { Suitable } \\
\text { Amount } \\
\text { of } \\
\text { Habitat }\end{array}$ \\
\hline 1 & $\begin{array}{l}\text { Globally unique or highest priority locally rare native } \\
\text { vegetation types. }\end{array}$ & $90 \%$ \\
\hline 2 & $\begin{array}{l}\text { Locally rare native vegetation types comprising 5\% or less } \\
\text { of a landscape unit. }\end{array}$ & $75 \%$ \\
\hline 3 & $\begin{array}{l}\text { Locally and globally common vegetation types, also referred } \\
\text { to as matrix species, comprising more than 5\% of a } \\
\text { landscape unit. }\end{array}$ & $50 \%$ \\
\hline 4 & $\begin{array}{l}\text { Converted Lands that include Urban, Cultivated Agriculture, } \\
\text { or Rural Residential land use areas that do not contribute to } \\
\text { biodiversity. }\end{array}$ & 0 \\
\hline
\end{tabular}




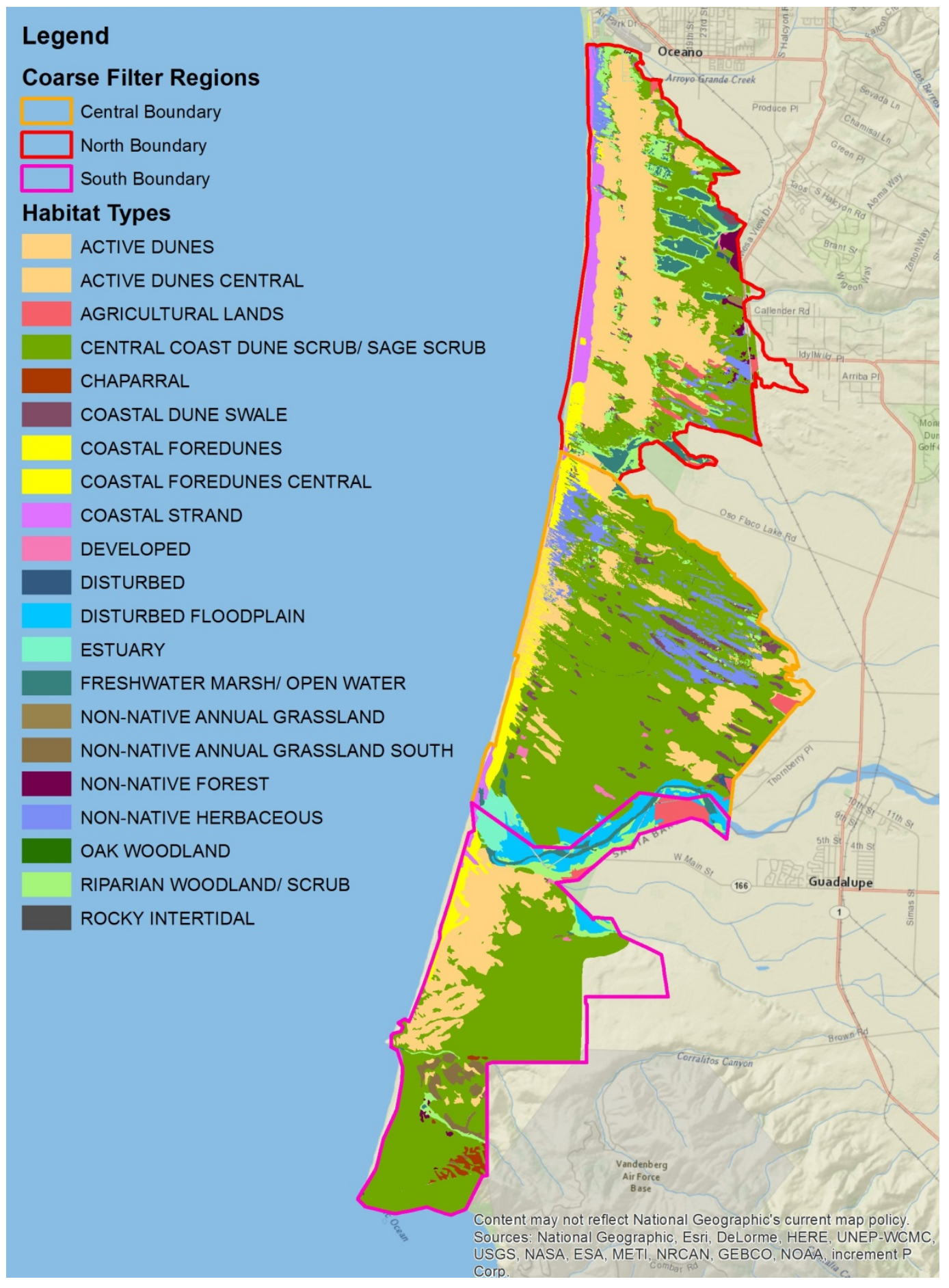

Figure 3: Habitat Types. Habitat types not included in the region are converted agricultural lands and were not included in analysis. 
Table 2: Coarse Filter Rankings. Coarse Filter vegetation types chosen and ranked by working groups according to rarity. *Southern non-native grassland has not been ground-truthed for possible native grassland so it was chosen to have a high ranking for possible rarity.

\begin{tabular}{|l|l|l|l|}
\hline Vegetation Type & North & Central & South \\
\hline Active Dunes & $50 \%$ & $75 \%$ & $50 \%$ \\
\hline Central Coast Dune Scrub/Sage Scrub & $75 \%$ & $75 \%$ & $75 \%$ \\
\hline Chaparral & $90 \%$ & $90 \%$ & $90 \%$ \\
\hline Coastal Dune Swale & $90 \%$ & $90 \%$ & $90 \%$ \\
\hline Coastal Foredunes & $90 \%$ & $75 \%$ & $90 \%$ \\
\hline Coastal Strand & $50 \%$ & $50 \%$ & $50 \%$ \\
\hline Disturbed Floodplain & $90 \%$ & $90 \%$ & $90 \%$ \\
\hline Estuary & $90 \%$ & $90 \%$ & $90 \%$ \\
\hline Freshwater Marsh/ Open Water & $90 \%$ & $90 \%$ & $90 \%$ \\
\hline Non-native Grassland & $0 \%$ & $0 \%$ & $90 \%$ \\
\hline Non-native Forest & $50 \%$ & $50 \%$ & $50 \%$ \\
\hline Non-native Herbaceous & $0 \%$ & $0 \%$ & $0 \%$ \\
\hline Oak Woodland & $75 \%$ & $75 \%$ & $75 \%$ \\
\hline Riparian Woodland/Scrub & $90 \%$ & $90 \%$ & $90 \%$ \\
\hline Rocky Intertidal & $90 \%$ & $90 \%$ & $90 \%$ \\
\hline Developed/Disturbed & $0 \%$ & $0 \%$ & $0 \%$ \\
\hline
\end{tabular}

Fine Filters Conservation Targets. Each working group used the LCSLOC's database to examine each taxonomic group individually. Each taxonomic working group was charged with assuring the data's accuracy and relevance to the conservation planning process as described below. Species were added and removed from the database and habitat requirements were noted for each species retained. Of the 760 confirmed species, 123 fine filter species were selected for inclusion in my analysis (Appendix B). Each working group's evaluation of the database and chosen method of inclusion in the model is explained below: 
Mammals: All mammals species included in the database were found to be sufficiently represented in the coarse filter habitat rarity rankings. Listed species were given a rank based on their California Endangered Species Act designation (Endangered: 45\%, Threatened: $35 \%$ and Species of Concern: $25 \%$ of designated habitat must be included in the output of each model).

Rare Plants: Rankings for the rare plant fine filter were roughly chosen from the California Native Plant Society's Rare and Endangered Plant Inventory. Giant Coreopsis (Leptosyne gigantean Kellogg), Western Pond Lily (Nuphar polysepala Engelm) and Branching Phacelia (Phacelia ramosissima Lehm) were also included due to their relevance to the area.

Birds: Bird species were selected for inclusion if there was record of breeding pairs or a reasonable notion of possible breeding pairs to be found in the GNDC according to expert knowledge supported by biological reports from California State Parks, California Nature Diversity Database and Dunes Collaborative Biological Surveys (Terrestrial Faunal Resources, 2006). Species chosen were then ranked based on how many mating pairs are presumed to be in the GNDC. Rare (very few, unlikely to be seen, infrequent breeding pairs) received a rank of $45 \%$ of designated habitat in model output, uncommon (possible to see on any given day, not predictable in habitat, consistent but uncommon) received a rank of 35\%of designated habitat in model output, common (likely to be seen in appropriate suitable habitats in breeding season) received $25 \%$ of designated habitat in 
model output and all other species were not included for there is no need to promote breeding habitat of these species.

Reptiles and Amphibians: All reptile and amphibian species included in the database were found to be sufficiently represented in the course filter habitat rarity rankings. Listed species were given a ranking based on their California Endangered Species Act designation (Endangered: 45\%, Threatened: 35\% and Species of Concern: $25 \%$ of designated habitat must be included in the output of each model).

Taxonomic Groups Not Included: Invertebrates and Lichens were considered for inclusion in the conservation planning process. There is a large gap in our understanding of invertebrates and lichens in the GNDC and for that reason, were excluded from the analysis.

\subsubsection{Conservation Planning Software}

The coarse filter and chosen fine filters conservation targets were evaluated by two different site selection algorithms: Marxan and Zonation. These software programs were chosen from other selection software programs because of their professional resumes and unique styles (Wintle, 2008). Marxan was selected because of its wide acceptance in the professional community as the best tool (Delavenne et al., 2012; Wintle, 2008). It has been used in many large scale and high profile projects such as the Great Barrier Reef and the Channel Islands off the coast of California (Airamé et al., 2003; Fernandes et al., 2005). Its method is well known and well understood (Wintle, 2008). Zonation is less 
well known (with most of its products in Australia and New Zealand) but is able to address some of the shortcomings cited in the Marxan algorithm (Kremen et al., 2008; Lehtomäki \& Moilanen, 2013). Zonation is also used in site prioritization and has a stronger focus on connectivity than Marxan (Delavenne et al., 2012). For these reasons both software programs were selected to be used in this analysis.

There are preliminary assumptions outlined in the user manuals of these software programs that must be considered when implementing any suggested results. Knowledge about data quality cannot always be incorporated, especially in the case of the spatial distribution of data used. These software program assume all data input to be consistent (Game et al., 2008; Moilanen et al., 2014). For example, detection rate of a certain species is usually higher near accessible places and under represented in areas more difficult to collect information. This is not represented in this type of conservation planning software. In cases where the distribution of a species is uncertain, biophysical data acts as a more reliable surrogate (Game et al., 2008; Moilanen et al., 2014). They also do not assume uncertainty of data. They assume all data is representative and have equal value (Game et al., 2008). These assumptions are very important when implementing the output of these software programs. Special consideration should be made when selecting input data for both Marxan and Zonation to insure the output can be trusted and is representative of the data.

The goal of Marxan is to achieve a set of biodiversity conservation targets in the minimum amount of space, or cost. Marxan is best known for using a simulated 
annealing algorithm, an optimization method which adapts its selection method with each repetitive run of a set of conservation targets (Mcdonnell, Possingham, Ball, \& Cousins, 2002). It allows for educated random searches that improve the algorithm's search for higher value areas. Simulated annealing is best described by comparing to metalsmith work. When annealing metal, you heat up the metal so it is pliable and ions move freely. As the metal cools, it becomes stiff and not malleable. In the beginning runs of Marxan, the searches for high value areas are broad and widespread and as the runs continue, they become less flexible and must chose areas nearest to other high value areas. This insures no locally high value areas are chosen before the entire system is evaluated. The selection algorithm for high value areas is adapted with each run of the same set of conservation targets. It also includes elements of connectivity and emphasizes minimizing the boundary length of chosen areas (Ball, Possingham, \& Watts, 2009). The output provides a number of good, near-optimal solutions very quickly which can then be given as options for planners and stakeholders to consider when planning for conservation (Game et al., 2008).

Scientifically cited conservation planning documents suggest Marxan selects small high value areas with a strong emphasis on conservation target rankings (Delavenne et al., 2012). Marxan is very accurate at picking areas with high conservation target rankings and thus more accurately identified the most diverse areas based on the conservation targets inputted into the model (Delavenne et al., 2012; Wintle, 2008). Criticisms of this method include its emphasis on high priority areas sometimes neglects the importance of connectivity and corridors in and around the study site (Wintle, 2008). 
Marxan 1.8.10 (Marxan, University of Queensland, Australia) requires input files of specific formatting that was achieved using Inedit, a support tool providing a graphical user interface for each of the parameters needed before implementing the Marxan model using polygon GIS layers (Game et al., 2008). All default settings in Marxan except for BLM (Boundary Length Modifier) and the PROP (Proportion of planning units in initial reserve system) were used in this assessment.

The BLM setting helps chose cells that are connected to one another. When increasing the BLM, the number of cells chosen is increased in order to connect isolated cells with many high-ranking conservation targets. A high BLM would make for a larger selected area that might include low priority cells but the selected areas would be more connected, which would be a more natural management method. A BLM of .0001 was selected after performing BLM efficiency analysis, which is a test of many BLM's to ensure the BLM is strong enough to influence the choices of the model and weak enough to not dominate over the conservation targets (Stewart \& Possingham, 2005). The ranking set by the working groups was used as the PROP value for each conservation target.

As the Marxan procedure manual suggests, the algorithm was ran 100 times with the adaptive simulated annealing algorithm and normal iterative improvement. Adaptive simulated annealing is based on a set number of runs (100 in this instance) and stochastic (random) acceptance of bad cells to help avoid choosing cells that appear to be highly ranked but are only locally highly ranked. This means the algorithm accepts lower ranked 
cells in the beginning and slowly strengthens the restrictions on inclusion until they only include broadly high ranked cells (broad searches in the beginning and restricted local searches in later runs). The user manual advises the normal iterative improvement as a low-powered but effective partner when using simulated annealing. The normal iterative improvement algorithm is used solely to ensure that no further simple improvements are possible by reviewing chosen cells to make sure they are optimal (Game et al., 2008). The annealing controls were set to Adaptive, the standard setting for how quickly the algorithm becomes stricter on cells' inclusion in the output. Each of the algorithm runs can be displayed using ArcView GIS 10.3 interface. Of the 100 runs, each cell was either selected to be included within an area of high conservation value (1) or in an area of low conservation value (0) based on its final score at the end of each run. ArcVeiw (ArcGIS 10.3) can then use information to create a gradient of which cells where selected as high priority in the most runs.

Zonation was also used to assess and rank areas of conservational importance for the GNDC. This program was used in conjunction with Marxan because of its alternative methods of selection of important conservation areas but comparable output (Delavenne et al., 2012; Wintle, 2008). Zonation produces a hierarchy of conservation priority areas throughout a given region by starting with inclusion of every cell and then iteratively removing cells with the lowest value of the remaining area (Moilanen \& Wintle, 2007; Moilanen et al., 2014; Wintle, 2008). The rank of conservation targets in each of the cells dictates which cells will be removed. It removes cells of lowest value until there are no cells at all. This allows you to interpret the included cells at each removal point (the 
remaining cells at $10 \%, 20 \%$, etc. of the total area). It includes a set of useful analysis features including uncertainty analysis and seven ways of dealing with connectivity (Lehtomäki \& Moilanen, 2013). Zonation is only calculated once and will produce the same output for each set of conservation targets (Moilanen et al., 2014).

Zonation holds strengths in its ability to interpret connectivity into the results. Output from the Zonation model tends to produce networks of larger clump size with accessible options for connectivity and corridors (Delavenne et al., 2012). With the focus on larger clump size, the rankings of the conservation targets are not as heavily weighted in the final results (Delavenne et al., 2012; Wintle, 2008).

The input information was compiled in Zonation GUI 4.0 (Zonation, University of Helsinki, Finland) using the Zonation GUI Project Maker. Each conservation target was put into the project maker and the, "weight" was set according to the conservation target ranking. Each conservation target was its own individual raster layer as an ArcView, GIS file. The standard settings of the algorithm were used except the weight and Boundary Length Penalty (BLP), as recommended by the Zonation version 4 manual (Moilanen et al., 2014).

The BLP is the penalty given for fragmentation of the cells in the chosen conservation priority area and works similar to Marxan's BLM. It is suggested to keep the BLP low and was set at 0.0001 to correspond with the Marxan model (Moilanen et al., 2014). The ranking system for each of the conservation targets set by the working groups was used 
as the, "weight" value for each conservation target. Zonation was run with the rest of the standard settings using the Additive Benefit Function (ABF) Removal Rule (takes into account all of the rankings of conservation targets within a given cell instead of just the highest rank) with edge removal (only removing cells from the edge) and a warp factor of 1 (one cell is removed at a time). The Zonation algorithm was run one time. The output does not vary between runs if the inputs remain the same. The algorithm output was displayed within Zonation and exported to ArcView (ArcGIS 10.3). Each cell is ranked on a scale between 1 (highly ranked by conservation targets as important to biodiversity) and 0 (the cell is replaceable).

\subsection{Results}

\subsubsection{Marxan}

Marxan displays the output based on the number of times a cell was highly ranked during the model's 100 runs. Figure 4 shows the areas selected as high conservation areas for this set of conservation targets. The top $50 \%$ of the total area of the GNDC is displayed in red (top 11\%), orange (next 10\%) and yellow (next 29\%). The corresponding habitats for the top $21 \%$ of chosen cells (red and orange cells of Figure 4 ) are presented in Figure 6A. All habitats considered in the model are represented. Major habitats selected include Central Coast Dune Scrub/ Sage Scrub (33.53\%) and Riparian Woodland/ Scrub (18.11\%). Habitats associated with water also had significant acreage in the model output with Disturbed Floodplain (9.83\%), Freshwater Marsh/ Open Water and Dune Swale (6.52\%). Oak Woodland, Rocky Intertidal and Nonnative Forest have very low representation throughout the GNDC, so their representation is small in the top selected 
acreage. Other low representation includes Agricultural Lands, Developed, Disturbed, nonnative Annual Grassland and Nonnative Herbaceous which all receive very low rankings in the course filter conservation targets.

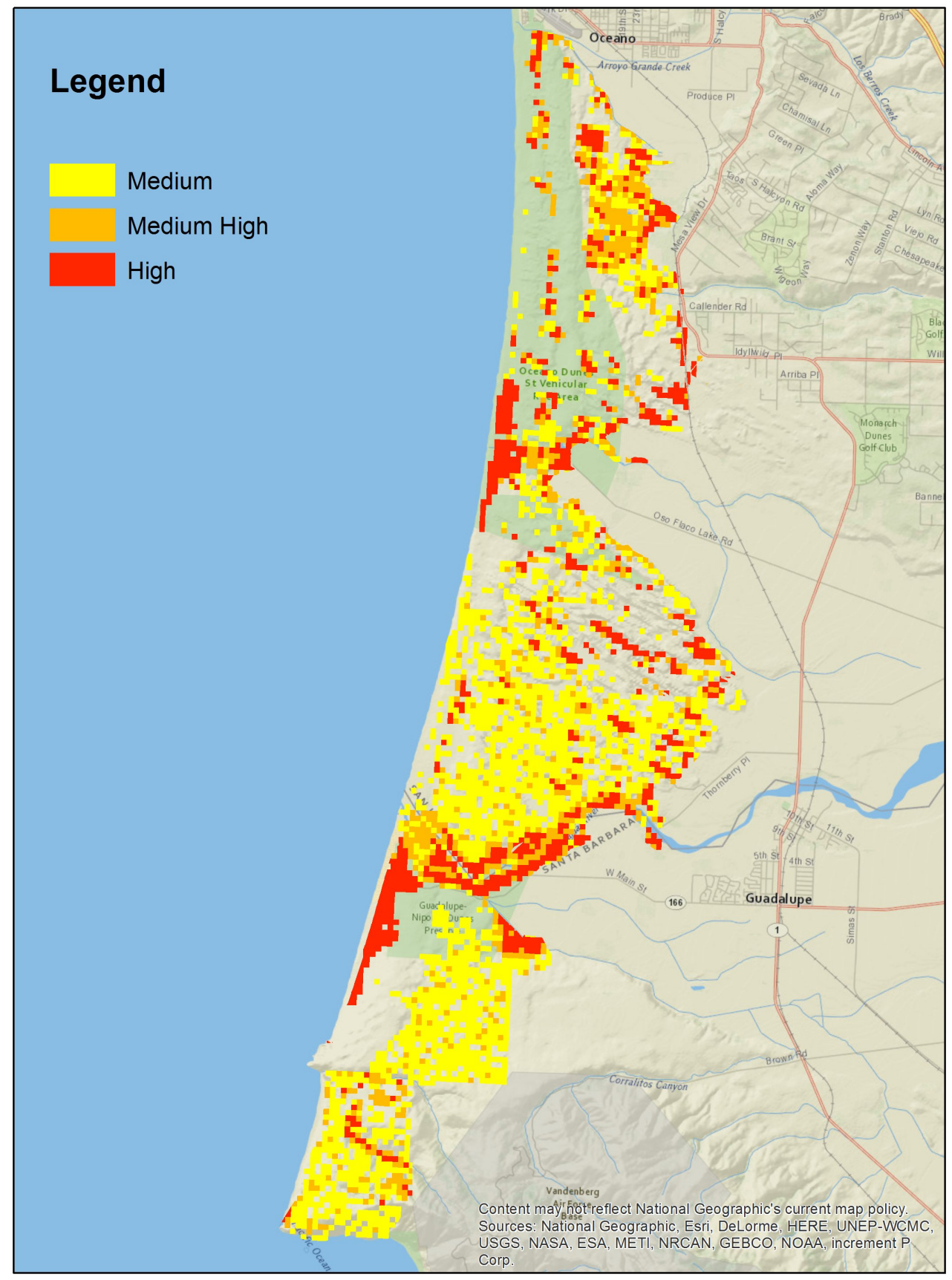

Figure 4: Marxan Output. Marxan's output for the list of conservation targets. Only the top $50 \%$ of the total area of the complex is displayed with the areas in red beginning of the highest priority for conservation. Secondary areas include orange/yellow-labeled areas. 


\subsubsection{Zonation}

Zonation operates by selecting areas of high conservation value by first selecting the entire complex and then evaluating each cell as it moves through the complex. Output from the Zonation model is displayed in Figure 5. The top 50\% of the total area of the GNDC is displayed in Figure 5, with the highest priority areas in red (11\%), medium high priority in orange $(10 \%)$ and medium priority areas in yellow (29\%). Habitats selected in the orange and red selected areas (the top $21 \%$ of total acreage) are displayed in Figure 6B. All habitats considered in the model are represented. Major habitats represented were Central Coast Dunes Scrub/ Sage Scrub (24.41\%) and Riparian Woodland/ Scrub (19.65\%). Habitats near water sources are represented with high acreage in Freshwater Marsh/ Open Water (11.72\%), Dune Swale (6.36\%) and Estuary (3.74\%). Oak Woodland, and Rocky Intertidal have very low representation throughout the GNDC, so their representation is small in the top selected acreage. Other low representation includes Agricultural Lands, Developed, Disturbed, and Nonnative Annual Grassland which all receive very low rankings in the course filter conservation targets.

\subsubsection{Comparison of Top 11\% of Selected Area}

When only the top $11 \%$ of area selected (only the red portion of Figures $4 \& 5$ ) are compared in each of the models, only $32 \%$ or 618.64 acres of selected area overlap (Figure $7 \%$ Table 3). The location in which cells were selected is similar between the two models even though many of the cells were selected differently. 


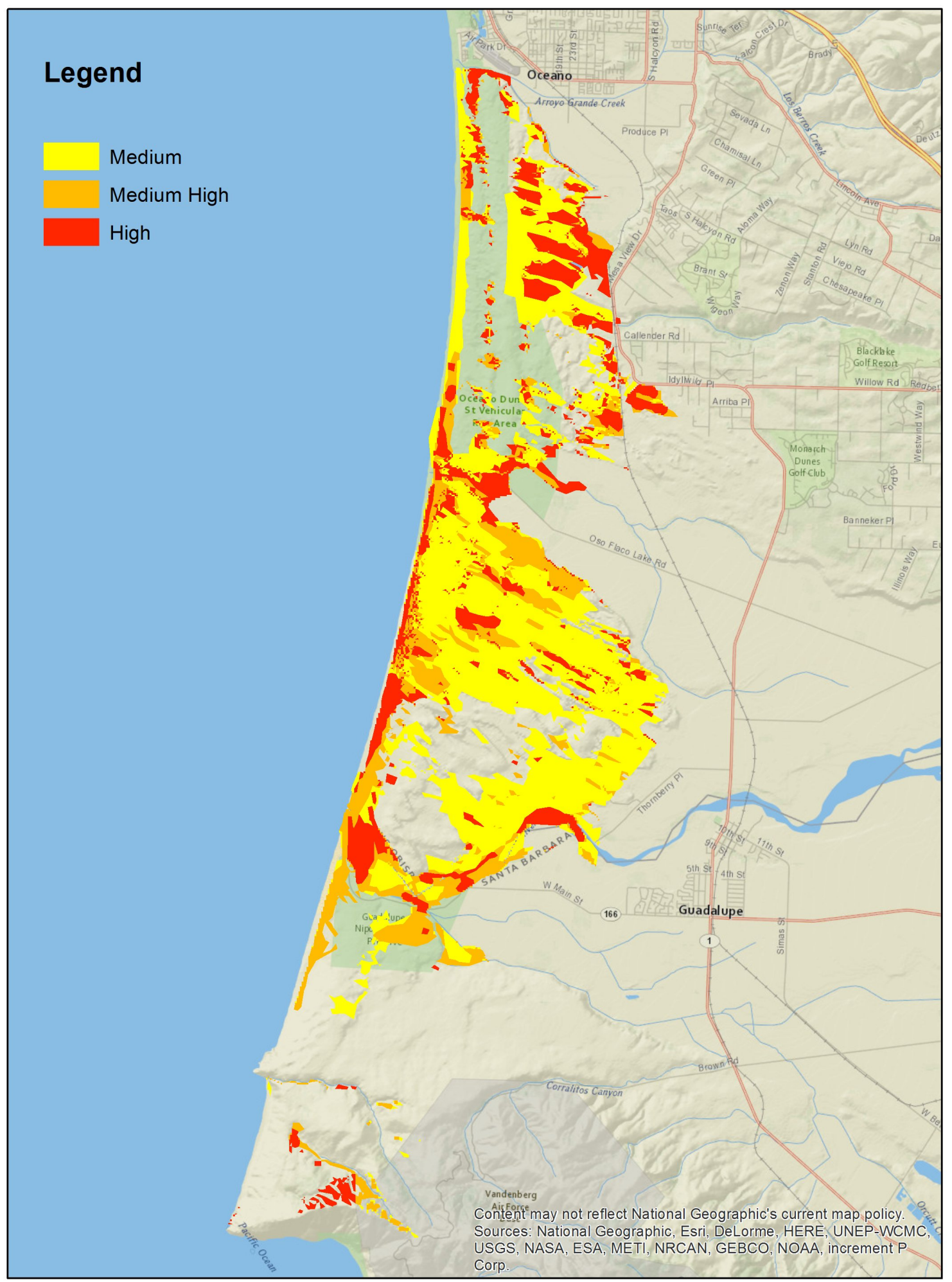

Figure 5: Zonation Output. Zonation calculates the output by evaluating cells based on conservation targets ranks compared to the neighboring cells slowly eliminating lower ranked areas. Areas in red are the areas of highest conservation value with orange and yellow areas ranked slightly lower. 


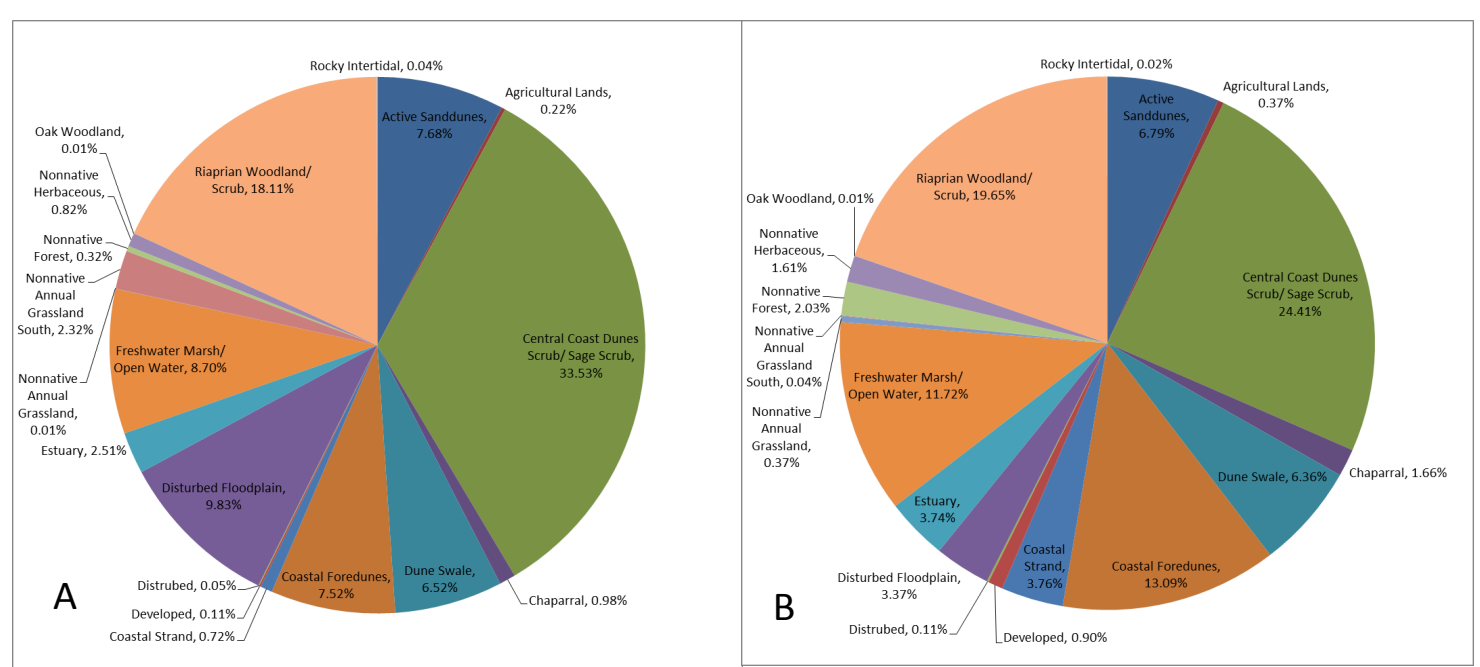

Figure 6: Top Areas by Habitat. The top 21\% of total area selected by A) Marxan and B) Zonation broken down by habitat type. All habitat types were represented in each of the models.

\section{Table 3: Habitat Types Represented in Selected Areas.}

\begin{tabular}{|l|r|r|}
\hline Habitat Type & \multicolumn{1}{|l|}{ Marxan } & \multicolumn{1}{l|}{ Zonation } \\
\hline Active Sand & $7.68 \%$ & $6.79 \%$ \\
\hline Agricultural Lands & $0.22 \%$ & $0.37 \%$ \\
\hline Central Coast Dunes Scrub/ Sage Scrub & $33.53 \%$ & $24.41 \%$ \\
\hline Chaparral & $0.98 \%$ & $1.66 \%$ \\
\hline Dune Swale & $6.52 \%$ & $6.36 \%$ \\
\hline Coastal Foredunes & $7.52 \%$ & $13.09 \%$ \\
\hline Coastal Strand & $0.72 \%$ & $3.76 \%$ \\
\hline Developed & $0.11 \%$ & $0.90 \%$ \\
\hline Disturbed & $0.05 \%$ & $0.11 \%$ \\
\hline Disturbed Floodplain & $9.83 \%$ & $3.37 \%$ \\
\hline Estuary & $2.51 \%$ & $3.74 \%$ \\
\hline Freshwater Marsh/ Open Water & $8.70 \%$ & $11.72 \%$ \\
\hline Nonnative Annual Grassland & $0.01 \%$ & $0.37 \%$ \\
\hline Nonnative Annual Grassland South & $2.32 \%$ & $0.04 \%$ \\
\hline Nonnative Forest & $0.32 \%$ & $2.03 \%$ \\
\hline Nonnative Herbaceous & $0.82 \%$ & $1.61 \%$ \\
\hline Oak Woodland & $0.01 \%$ & $0.01 \%$ \\
\hline Riparian Woodland/ Scrub & $18.11 \%$ & $19.65 \%$ \\
\hline Rocky Intertidal & $0.04 \%$ & $0.02 \%$ \\
\hline
\end{tabular}




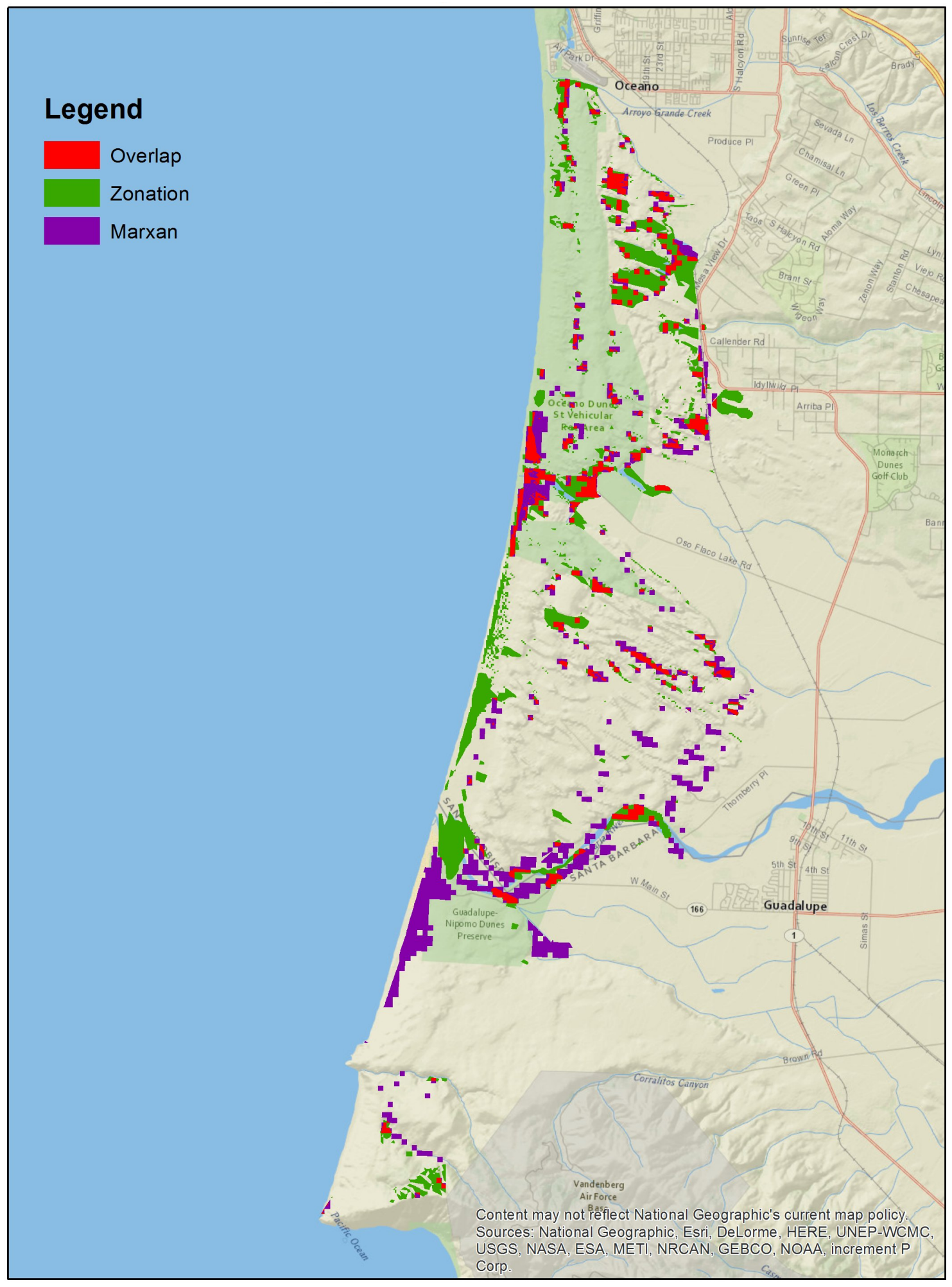

Figure 7: Comparison of Top 11\% of Chosen Area. The top ranked areas in each model (Zonation in green and Marxan in purple) and the overlapping areas in both models (red). Overlapping area is 618.84 acres or $32 \%$ of the entire complex. 


\subsection{Discussion}

The world's species are in decline for many reasons, most of which can be attributed to human activity. The decrease in species negatively impacts many important cycles which drive ecological processes such as capturing essential resources, producing biomass, decomposing and recycling essential nutrients (Cardinale et al., 2012). Preserving and promoting biodiversity is of upmost importance. The Guadalupe Nipomo Dunes Complex offers a unique opportunity to use conservation planning software to select areas of high biodiversity for future resource allocation.

With the assistance of local expert biologists and ecologists, conservation targets were accurately selected and ranked. The information from these working groups has helped document the presence of species and vegetation types that can be used as a timestamp for the GNDC. Future resource allocation can use this information to evaluate the status of species and plan resource accordingly. These conservation targets were very important in the selection of areas of high biodiversity by Marxan and Zonation.

Marxan and Zonation software programs used the conservation targets chosen by the working groups to select areas of high biodiversity. Areas selected by the models were different but shared many similar attributes. Both models chose areas surrounding water bodies with a diversity of habitat types. Oso Flaco Lake was selected as high priority area by both model outputs and offers a good example of the type of areas the models selected. Oso Flaco Lake is the largest fresh water lake in the GNDC and is surrounded by a variety of habitat types (Figure 8). Gradients of habitats can be found around Oso 
Flaco Lake that are important to the preservation of biodiversity as well as emphasized in the both of the models. Around Oso Flaco Lake there are Riparian Woodland, Central Coast Dune Scrub/ Sage Scrub and Coastal Dune Swale habitats. The transect from the Pacific Ocean moving east also includes Coastal Strand, Coastal Foredunes, and Freshwater Marsh habitats. This pocket of diverse habitats demonstrates the effectiveness of the models to selected area of high biodiversity that are important for current and future resource allocation and management.

Our model output for both Marxan and Zonation supported the literature in their behaviors. Marxan selected very specific locations of high priority with less emphasis on connectivity and corridor availability. Zonation selected larger, clumped areas with less influence on the conservation target rankings. High priority areas were usually located on or near the edge of the study to support movement in and out of the system. The strengths of each model were helpful in the identification of conservation areas.

Conservation planning tools could also be revisited periodically with updated information. The effectiveness of current efforts could be measured as well as reevaluated for new priority areas. As new information is collected in the field about each conservation target, the model can draw an even more accurate picture of the current priority areas. 


\section{Legend}

\begin{tabular}{|c|c|}
\hline Habitat Types & DISTURBED \\
\hline ACTIVE DUNES & DISTURBED FLOODPLAIN \\
\hline ACTIVE DUNES CENTRAL & ESTUARY \\
\hline AGRICULTURAL LANDS & FRESHWATER MARSH/ OPEN WATER \\
\hline CENTRAL COAST DUNE SCRUB/ SAGE SCRUB & NON-NATIVE ANNUAL GRASSLAND \\
\hline CHAPARRAL & NON-NATIVE ANNUAL GRASSLAND SOUTH \\
\hline COASTAL DUNE SWALE & NON-NATIVE FOREST \\
\hline COASTAL FOREDUNES & NON-NATIVE HERBACEOUS \\
\hline COASTAL FOREDUNES CENTRAL & OAK WOODLAND \\
\hline COASTAL STRAND & RIPARIAN WOODLAND/ SCRUB \\
\hline DEVELOPED & ROCKY INTERTIDAL \\
\hline
\end{tabular}

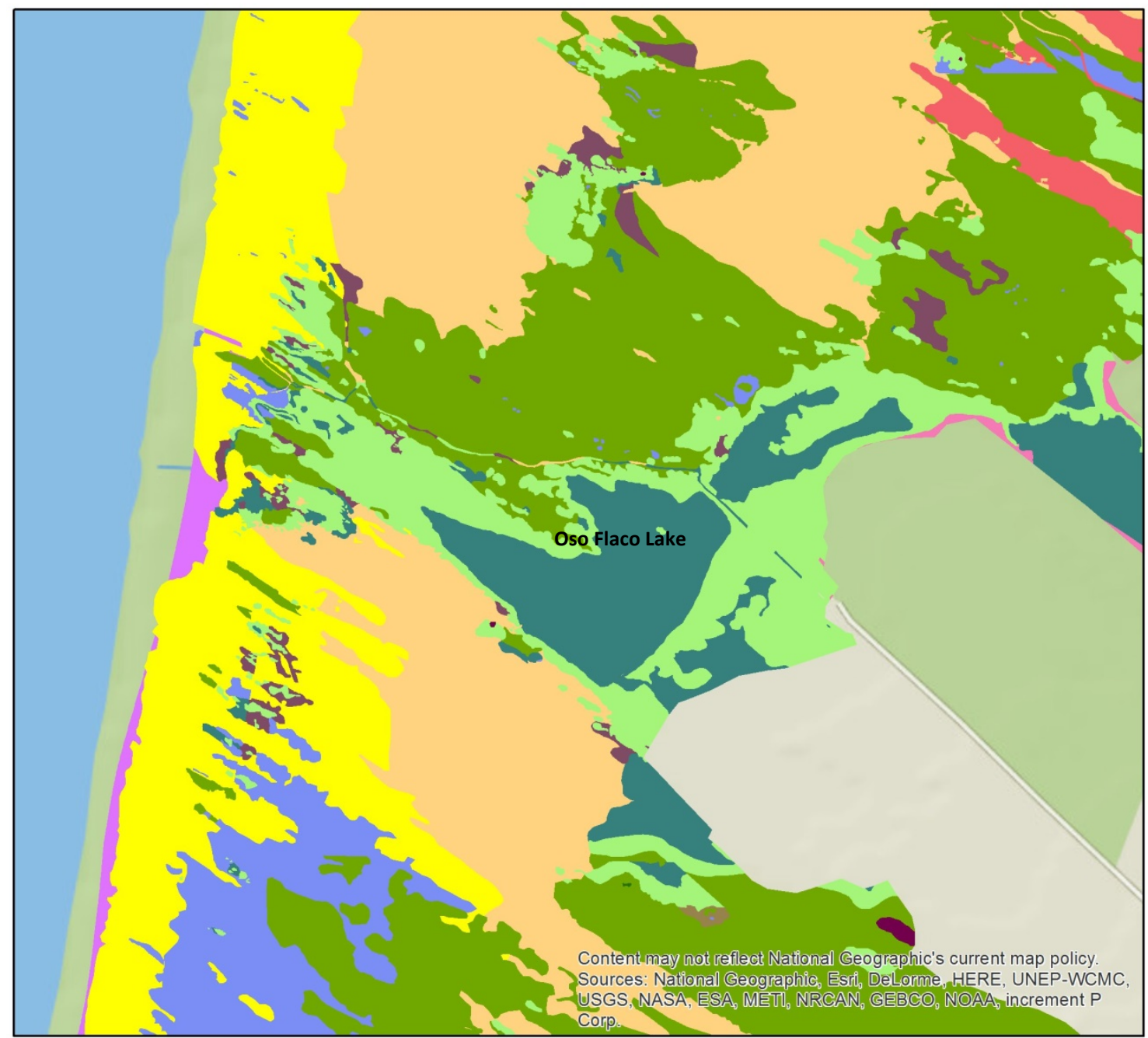

Figure 8: Selected Area, Oso Flaco Lake. Oso Flaco Lake was selected by both of the models as an important area for resource allocation because its diversity of habitats. 
These models would benefit from additional species and processes information. The current input to the models is solely based on habitat and there are limitations to using habitats as the only criterion for conservation prioritization (Pressey et al., 2003;

Rodrigues \& Brooks, 2007; Ward, Vanderklift, Nicholls, \& Kenchington, 1999). Habitat maps provide a snapshot of physical and ecological conditions at one point or interval in time (Airamé et al., 2003). The static nature of most of the data on habitat distributions does not account for environmental variation and climatic regime shifts. A more advanced model could also include variable behaviors of individuals and populations (Airamé et al., 2003). In order to implement these additional tools, more information on species and their relationship to the coastal dune habitats needs to be collected.

The final product from each model's output was shared with the Dunes Collaborative, the overseeing organization for all conservation work in the GNDC. Each model's method of selection was explained and major similarities and differences were described. The group was able to use the modeling products as starting point for selection of resource allocation. These are areas of high biodiversity and importance to the GNDC ecosystem. Areas selected both by the group and by the model hold a level a transparency and impartiality that will allow the Dunes Collaborative to obtain additional conservation funds.

This study illustrates the achievability of using biodiversity conservation planning software with minimal data and professional community participation as a practical and feasible solution to conservation prioritization. With limited data, the Marxan and 
Zonation conservation prioritization software have created a starting point for discussion and selection of high conservation value areas. The conservation planning process and software was able to create an unbiased and transparent springboard, which will launch resource allocation into the most appropriate and biodiverse areas of the Guadalupe Nipomo Dunes Complex. 


\section{CHAPTER 2}

\section{ADVANCEMENTS IN THE UNDERSTANDING OF INVASIVE SPECIES, EHRHARTA CALYCINA, PERENNIAL VEDLTGRASS IN CALIFORNIA'S}

\section{COASTAL ECOSYSTEMS}

\subsection{Introduction}

Introduced species face a very difficult path when presented with a new environment. The lack of correct habitat conditions, specialize pollinators, and competition from native species are major barriers to the introduction of new species (Mack et al., 2000). Those species which are successful in integrating into the new environment are well adapted to succeed. They are able to thrive in a new climate, find pollinators and mates and exploited a niche in the habitat. These characteristics make them strong competitors and allow them to thrive in new environments. Species that are able to establish and reproduce are still very unlikely to become invasive. It is estimated only $0.1 \%$ of all plant species introduced outside their native ranges by humans become invasive (Williamson \& Fitter, 1996). Those invasive species, however, pose a significant threat to native ecosystems.

Invasive plant species ability to compete outside their native range can be contributed to a set of characteristics varying per habitat and per species. Peter Alpert describes an invasive plant species as one that both spreads in space and has negative effects on species already in the space that it enters" (Alpert, 2000). Most invasive species are characterized by having a broad native range and rapid, effective dispersal (Bazzaz, 1991; 
Mack et al., 2000). Rapid dispersal is usually associated with short germination time, long fruiting period, large seed number, small seed size, prolonged seed viability and dependence on non-specific mutualisms (Alpert, 2000; Pyšek \& Richardson, 2010; Rejmánek, 2000; Sakai et al., 2016). Many invasive species are able to adapt to changing conditions and thrive in disturbed environments (Thompson, 1991). These characteristics are even more successful with the ever-increasing damages and threats presented by human interaction with the natural world (Alpert, 2000; Cardinale et al., 2012; Inderjit, 2005; Myers et al., 2000).

Introduced species are the second-leading cause (after habitat degradation/loss), causing or contributing to the decline in species (Wilcove et al., 1998; Wilson, Rapson, Sykes, Watkins, \& Williams, 1992). Specifically, invasive species have also been strongly implicated in the reduction of native biodiversity (Daehler \& Strong, 1994; Maron \& Marler, 2008; Vila \& Weiner, 2004; Wilcove et al., 1998) and alteration of ecosystem functions (Byers et al., 2002; D’Antonio \& Vitousek, 1992; Ehrenfeld, 2003; Gordon, 1998; Liao et al., 2008; Loreau, 2008; Mack et al., 2000; Pimentel, Lach, Zuniga, \& Morrison, 2000; Rout \& Callaway, 2009). In a meta-analysis of threatened and listed species in the United States, $57 \%$ of listed species were at risk of extinction because of introduced species (Wilcove et al., 1998).

Humans have been aiding in the dispersal of invasive species for millennia accidently or purposely (Di Castri, 1989; McKinney \& Lockwood, 1999). However most of the worst plant invaders introduced in the United States has been deliberate. Significant migrations 
of species began with the expansion of the Europeans into the Western world in the 1500s (Mack et al., 2000). The rise of the global economy has since aided in the dispersal of species across the world (Mack et al., 2000). Modern avenues for the migration of species around the world are urbanization, trade, and agriculture (Alpert, 2000).

Ehrharta calycina Smith., a perennial (sometimes annual, depending on soil moisture (Verboom, Moore, Hoffmann, \& Cramer, 2012) grass native to savanna grasslands of South Africa, was introduced to Australia in the late 1800's and then to the California coast in the 1940s for erosion control and then in the 1960s as a forage for grazing animals primary cattle (Figure 9) (Love, 1963; Rossiter, 1947; Smith, Bell, \& Loneragan, 1999; Vandenberg AFB, 1996). This highly invasive species has a native range that shares many similar attributes with the California coast with moderately low annual rainfall and Mediterranean climate (Love, 1963). Ehrharta calycina was a desirable species because of its perenniality, drought tolerance, capacity for persistence under low soil fertility conditions, quick relative growth rate (Verboom, Linder, \& Stock, 2004) and ability to establish under moderately strong competition from other species (Rossiter, 1947). These characteristics not only make it a strong rangeland foraging species but also a strong invasive species. The species has become a detriment to native biodiversity in Australia (Smith et al., 1999) as well as California (Vandenberg AFB, 1996). Critical habitat for many of the California coastal listed species is dangerously threatened by $E$. calycina and changing the coastal dune ecosystem dramatically (CESA, 2015; The Land Conservatory of San Luis Obispo County, 2011). 

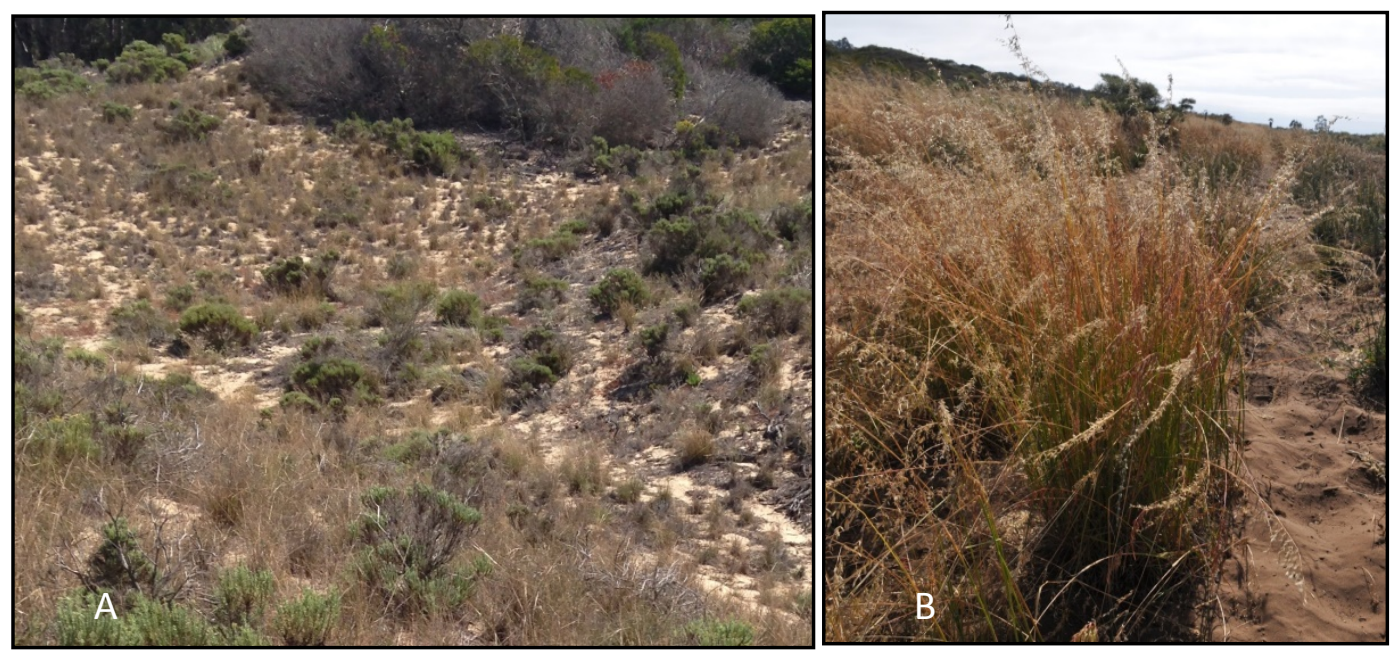

Figure 9: Ehrharta calycina in the Guadalupe Nipomo Dunes Complex. A) E.calycina can be seen invading open areas of coastal dune scrub habitat (pale grass surrounding evergreen coastal dune flora). B) E.calycina uses tillering to increase its diameter and protect itself against the difficult environment of the coastal dunes.

Ehrharta calycina has become highly invasive in the coastal dune communities of Central and Southern California and currently holds a "high" CAL-IPC inventory rating, defined as a species with severe ecological impacts on physical processes, plant and animal communities and vegetation structure as well as reproductive biology and other attributes conducive to moderate to high rates of dispersal and establishment. (California Invasive Plant Council, 2006). Ehrharta calycina is a prolific seeder and stores its seeds annually in the soil, collecting a substantial seedbank. A 1963 rangeland forage seed advertisement suggested E. calycina could produce well over 100 pounds of seed per acre (Love, 1963). The windy conditions of the coast also aids in dispersal of seeds.

Established individuals also can rapidly increase their size by tillering, a process done by many grass species in which multiple new stems develop from the parent shoot, quickly increasing the mass of each plant (Figure 9B) (Verboom et al., 2012). This has been confused in the literature as possible rhizomal activity (Verboon et al. 2012). After 
further examination, no rhizomes were found on any individuals in this system (Keil, personal communication, 2016). Clonal propagation is not a means by which E. calycina spreads from the maternal plant and seed is the primary method for establishment at new locations each year.

Not much is known about Ehrharta calycina, as its invasion into California coastal ecosystem is fairly young. Much of the little research on the species has been conducted South Africa (its home range) or in Australia which both host a different set of vegetation communities, competition and soil composition (Smith et al., 1999; Verboom et al., 2004, 2012). Management and control of E. calycina in California has been based on land managers understanding and traditional control methods (The Land Conservatory of San Luis Obispo County, 2003, 2011).

One of the most apparent and powerful characteristics of E. calycina is ability to store seeds for many years in the soil. An ecosystem's soil seedbank provides insight to possible changes in species dynamics and shifts in ecosystem processes (Fisher, Loneragan, Dixon, \& Veneklaas, 2009). With no rhizome activity found after close examination of many individuals, the distribution and storage of a large annual release of seeds is the major driver of dispersal. Effective management of invasive species requires detailed knowledge about the species' reproductive biology, including persistency of seed in the soil (Fenner \& Thompson, 2004). Studies of the fertility of the soils seedbank can assist in prediction of the future role that species will play in the ecosystem (Holmes, 2002). No experiment has documented the role of the seedbank in E. calycina's ability to 
invade the California coastal dune habitat so successfully. The Guadalupe Nipomo Dunes Complex offers a perfect location for this experiment.

The study system for this experiment is the Guadalupe Nipomo Dunes Complex (GNDC), which is located within the California Floristic Province, a biodiversity hotspot characterized by high rates of endemism and exceptional loss of habitat (Figure 2) (Myers et al., 2000). In 1980, the US Fish and Wildlife Service described the GNDC as, "the most unique and fragile ecosystem in the State of California," and ranked it first on a list of 49 habitat areas needing state protection. It is the largest coastal dune area in California and it is one of the last remaining relatively intact ecosystems of its type and size in the western United States (U.S. Fish and Wildlife Service, 2000).

The GNDC is located within San Luis Obispo and Santa Barbara Counties and spans the coast from Pismo Beach in the north to Point Sal in the south. The GNDC encompass over 17,000 acres and stretch along 18 miles of coastline (California Department and Fish Game, 1976). They support an abundant diversity of plant and animal species, many of which can only be found in this area. Examples of major habitat communities found within the GNDC include coastal dune scrub, riparian wetland, coastal dune swale and foredune mat (California Department and Fish Game, 1976; U.S. Fish and Wildlife Service, 2000).

This experiment aims to increase our understanding of the invasion success of E. calycina by answer the following questions: (1) does the seedbank contribute to the invasive success of E. calycina in the coastal dunes of the Guadalupe Nipomo Dunes Complex? 
(2) does seed deposited on the soil surface either dropped by the maternal plants or blown in from an outside location contribute more to propagation and establishment of $E$. calycina? (3) do other environmental factors contribute to differential success of propagation and establishment of E. calycina?

\section{2 Methods}

This field experiment was conducted on the Oceano California State Park in Nipomo, CA. An access agreement with California State Parks and the Land Conservancy of San Luis Obispo County was made in order to survey the sites weekly. Ten randomly selected sites were chosen from 18 locations where E. calycina was well established (Figure 10). Sites were chosen only if E. calycina was the dominant species (covered more than 30 percent of the area) with little to no native vegetation. No sites were selected on north facing aspects because there was far less E. calycina located on those aspects. North facing aspects have a much higher percent of native cover and fewer disturbances due to mosses and cryptogrammic soils which hold the soil in place. None of the possible sites in the study area on north facing aspects had a high enough cover of E. calycina. All of the sites were located along the southern property line of the Oceano State Parks.

At each selected site, two-one meter square plots were cleared. One plot was designated, "Seedbank Present," where only the surface vegetation and debris was removed (Figure 11A). This plot included seeds from the seedbank and seeds blown into the plot on the surface. The other plot was designated, "Seedbank Absent," where a mesh strainer (square weave of $1 \mathrm{~mm}$ ) was used to remove the seedbank (Figure 11B \&11C). The holes 
in the mesh strainer were sufficient in capturing all E. calycina seed as well as surface debris. Seedbank Absent plots were incased with $5 \mathrm{~cm}$ deep garden nursery trays. Research from the University of Western Australia on E. calycina found $99 \%$ of the seedbank is in the top $5 \mathrm{~cm}$ of the soil with almost $70 \%$ being in the litter at the surface (Smith et al 1999). This plot measured the effect of the seeds blown into the plots on the surface and excluded the seeds from the seedbank. Plots were considered disturbed if an animal significantly moved the garden nursery trays. A transect of $5 \mathrm{~cm}$ squares was used to determine the presence or absence of E. calycina in each of those squares (Figure 11D). This method was chosen based consultation with a turfgrass physiologist, Dr. Cole Thompson in accordance with turfgrass standards for effectively measuring coverage (Hoyle, Yelverton, \& Gannon, 2013; Thompson, personal communication, 2015). The plots were periodically surveyed over a nine-month period beginning in September 2015 and concluding in May of 2016. The plots were then compared to evaluate the role of the seedbank in the establishment of E. calycina. Slope and aspect were collected from each plot for supplementary analysis.

Each treatment (Seedbank Present $(\mathrm{n}=10)$ and Seedbank Absent $(\mathrm{n}=8))$ were averaged at each survey visit and graphed with standard error measurements excluding disturbed plots. Two plots were removed from the Seedbank Absent treatment group. Where standard error measurements exhibited significance, a T-Test was conducted on each of the significant survey dates to confirm or refute the significance. A T-Test is able to analyze two populations' samples and evaluate differences between the two populations. This test will allow us to look at all of the sample sites in each treatment group to fully 
evaluate if there is a significant difference between plots with the seedbank intact and those with the seedbank removed, where only seed blown in the from the surface are present.

Statistical analysis was performed using an MANOVA with repeated measures in JMP (JMP 12.2) to compare the two treatment groups over time. Multivariate analysis of variance (MANOVA) simply takes into account the correlation that exists among multiple measurements (i.e. multiple dependent variables) you make on the same experimental unit while assessing the effects of real interest: some independent variables. This analysis will allow us to look at a performance indicator (percent coverage) as it changes over time for a group of organisms (E. calycina) treated in some way (seeds coming from the seedbank and blown in on the surface) compared to another group treated another way (no seedbank with seeds blowing in from the surface). If the Seedbank Present plots (plots where seeds could be from the seedbank or blown in from the surface) are significantly different from the Seedbank Absent plots (plots where seeds can only blow in from the surface) we can deduce the seedbank plays a significant role in the success of invasion of E. calycina. The type of analysis assumes measurements taken closer in time are usually not as correlated as those taken further apart in time.

Slope and aspect were analyzed in JMP (JMP 12.2) using a bivariate fit regression of final percent coverage and slope and aspect, respectively. A bivariate fit regression shows the relationship between two continuous variables. Slope and aspect did not change throughout the experiment and final percent coverage was measured in May of 2016 for 
each plot. This analysis indicates if one continuous variable (slope or aspect) has a relationship with another continuous variable (final percent coverage). If a significant relationship is present, the final coverage of E. calycina is correlated with either slope or aspect, respectively.

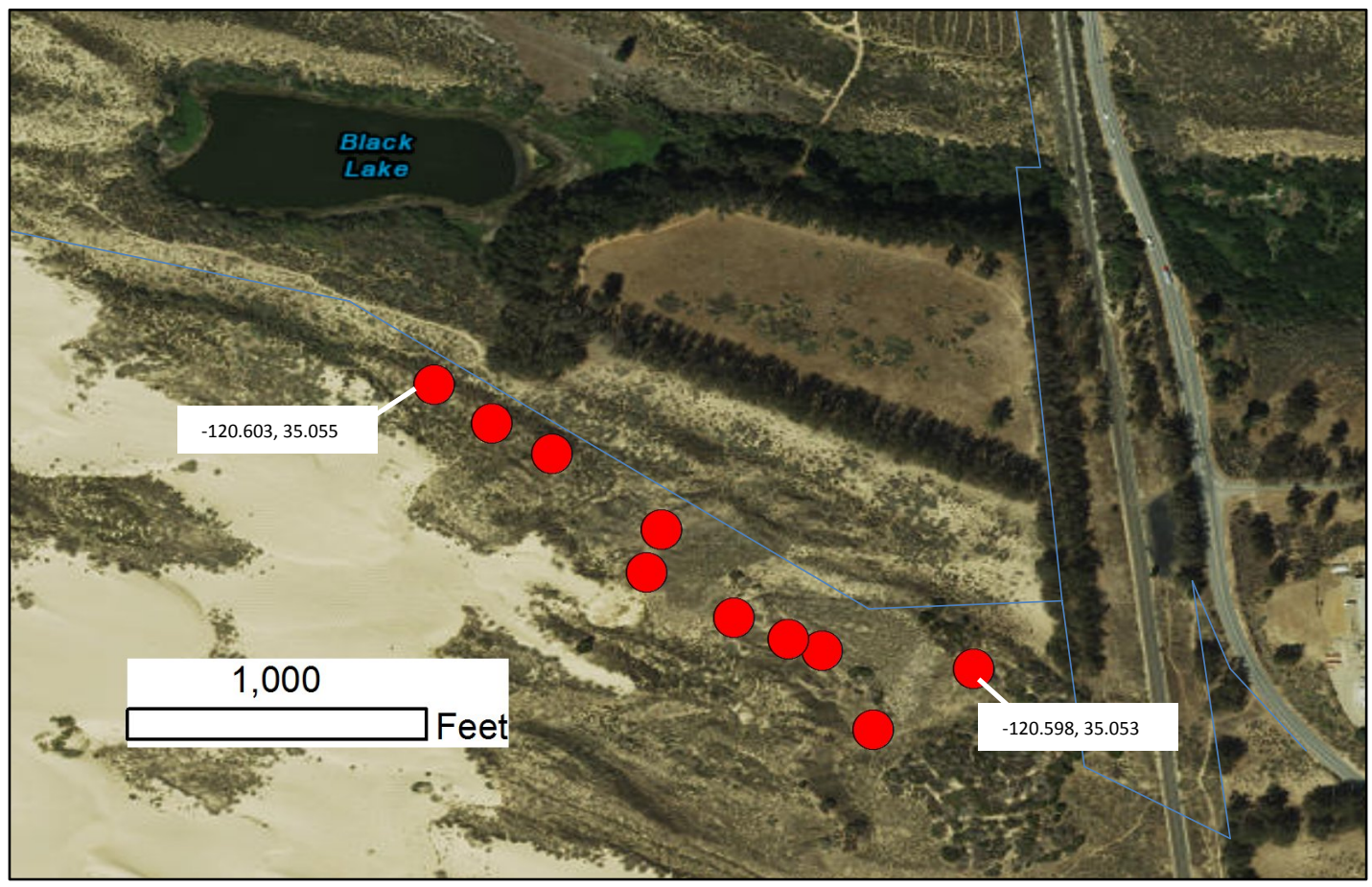

Figure 10: Site Locations. Map of the chosen sites along the southern border of the Oceano State Parks property (property line highlighted in blue). North of sites is the Land Conservancy of the San Luis Obispo County's Black Lake Ecological Area. 1,000 feet is indicated on the scale in the bottom left corner. 


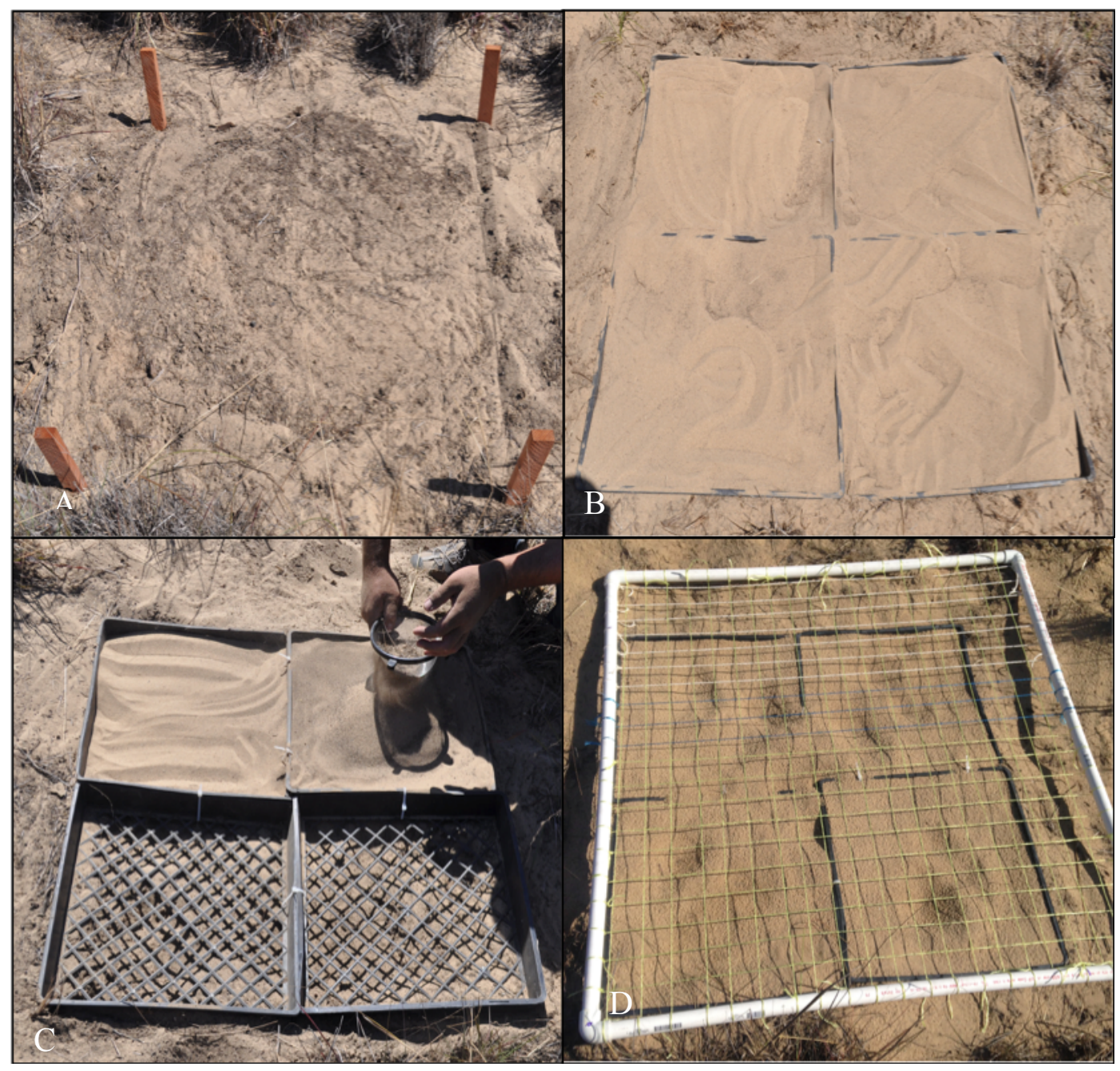

Figure 11: Plot Descriptions. A) Seedbank Present plot with only debris and vegetation removed with no alteration of the seedbank. B) Seedbank Absent plot with seedbank physically removed with general kitchen hand sifter. C) Visual demonstration of how seedbank was removed from Seedbank Absent plots. D) The presence/absence transect grid used to measure presence and absence in each of the plots.

\subsection{Results}

A comparison of Seedbank Present plots and Seedbank Absent plots are presented in

Figure 12. Visible coverage of E. calycina began 77 days (November 24, 2015) after plot installation. In the period between installation and 77 days the study area experienced 2.3 inches of rain (CIMIS data from September 9, 2015- November 24, 2015). After nine 
months of surveying, coverage reached 19\% in the Seedbank Present treatment and 21\% in the Seedbank Absent treatment. Through time, all plots experienced varying levels of increase in coverage. The Seedbank Present treatment group remained slightly higher in coverage than the Seedbank Absent treatment group until 244 days after plot installation, at which point the Seedbank Absent treatment had a higher percent coverage of $E$. calycina. The calculation of standard error for each surveyed visit through time did find significant differences in the treatments at three survey dates: 77, 143 and 150 days after installation of the plots. On further investigation, a T-Test for each of those significant dates found no significance between the Seedbank Present plots (seeds from the seedbank and blown in) and the Seedbank Absent plots (seeds blown in only, no seedbank) (77 days: $\mathrm{T}=1.57, \mathrm{p}$ value $=0.1429)(143$ days: $\mathrm{T}=1.26$, $\mathrm{p}$ value $=0.2243)(150$ days: $\mathrm{T}=1.60, \mathrm{p}$ value $=0.1297)$. These results were supported by the MANOVA with repeated measures which found no significant difference between the two treatment groups ( $F$ Test $=0.028$, $\mathrm{p}$ value $=0.511)$ or between treatment groups $\mathrm{x}$ time interaction $(\mathrm{F}$ Test $=9.117$, $\mathrm{p}$ value $=$ $0.1650)$. 


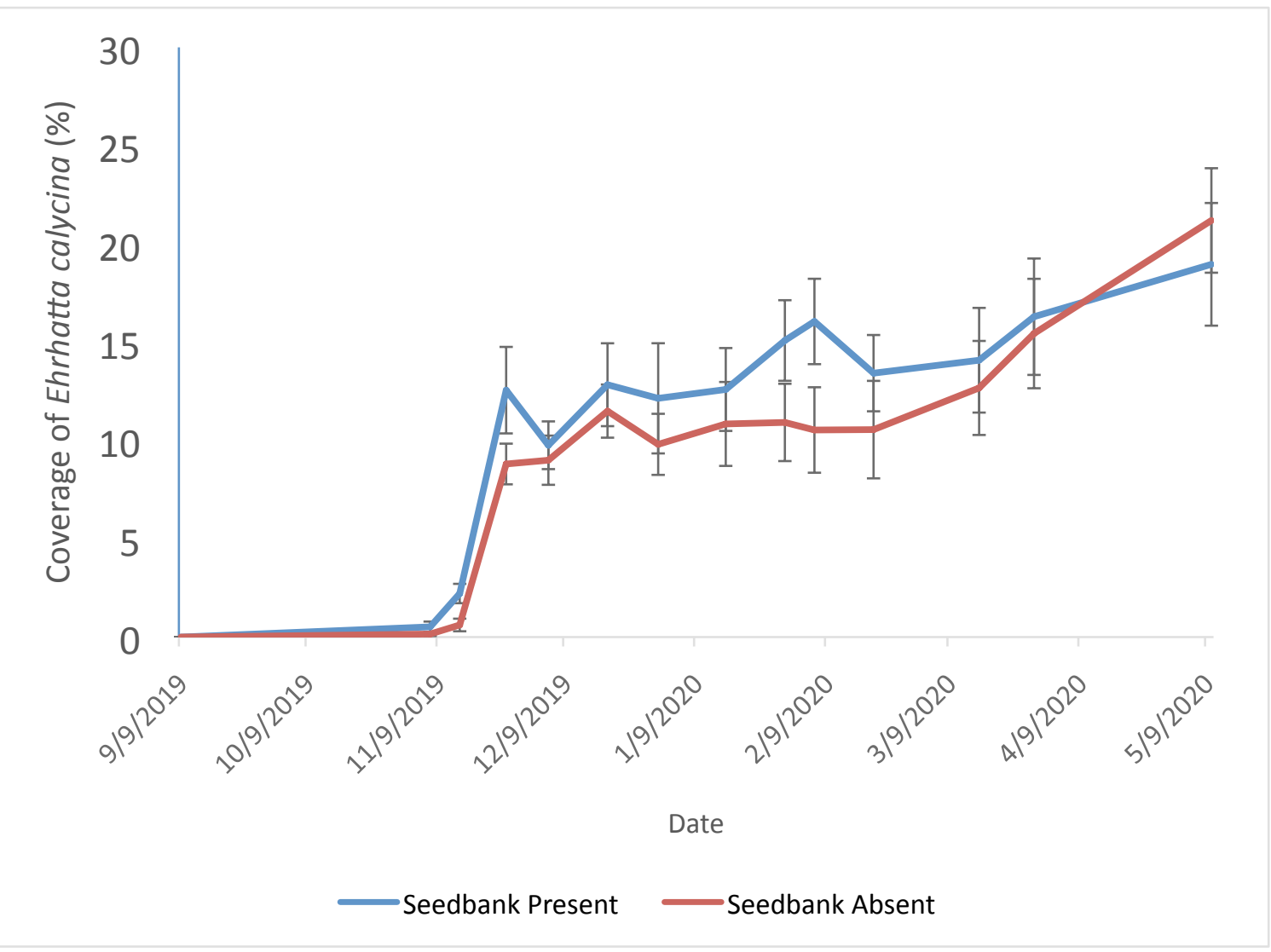

Figure 12: Percent Coverage of Ehrharta calycina in both Seedbank Present and Seedbank Absent treatments. Treatment type was not significant over time (F Test= 9.117, $p$ value $=0.1650)$.

The bivariate fit regression did not indicate a relationship between percent coverage and slope (Figure 13) or percent coverage and aspect (Figure 14 \&15). All plots had slopes between -23 degrees and - 6 degrees and aspects between 128 degrees (southeast) and 300 degrees (northwest). Anecdotal observations of the location supported areas of most $E$. calycina were on south facing aspects and varying degrees of slope. North and northeast facing slopes, especially those directly north, had higher density of native species and understory was dominated by mosses and cryptogrammic soils. These areas have visibly 
lower coverage of E. calycina.

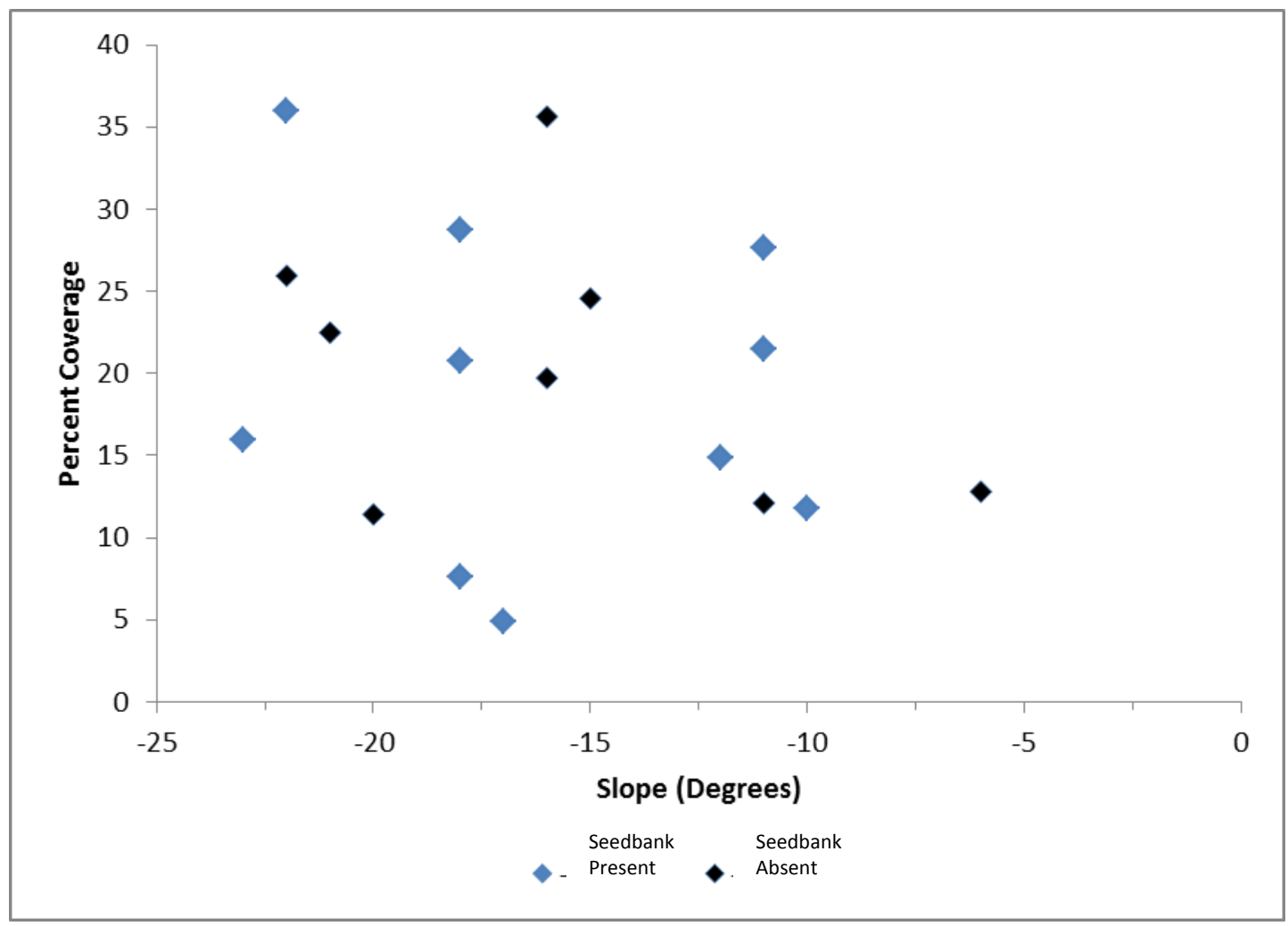

Figure 13: Percent Coverage by Slope. Plots of both treatment types were analyzed for possible relationship. Blue diamonds represent Seedbank Present plots and black diamonds represent Seedbank Absent plots. 


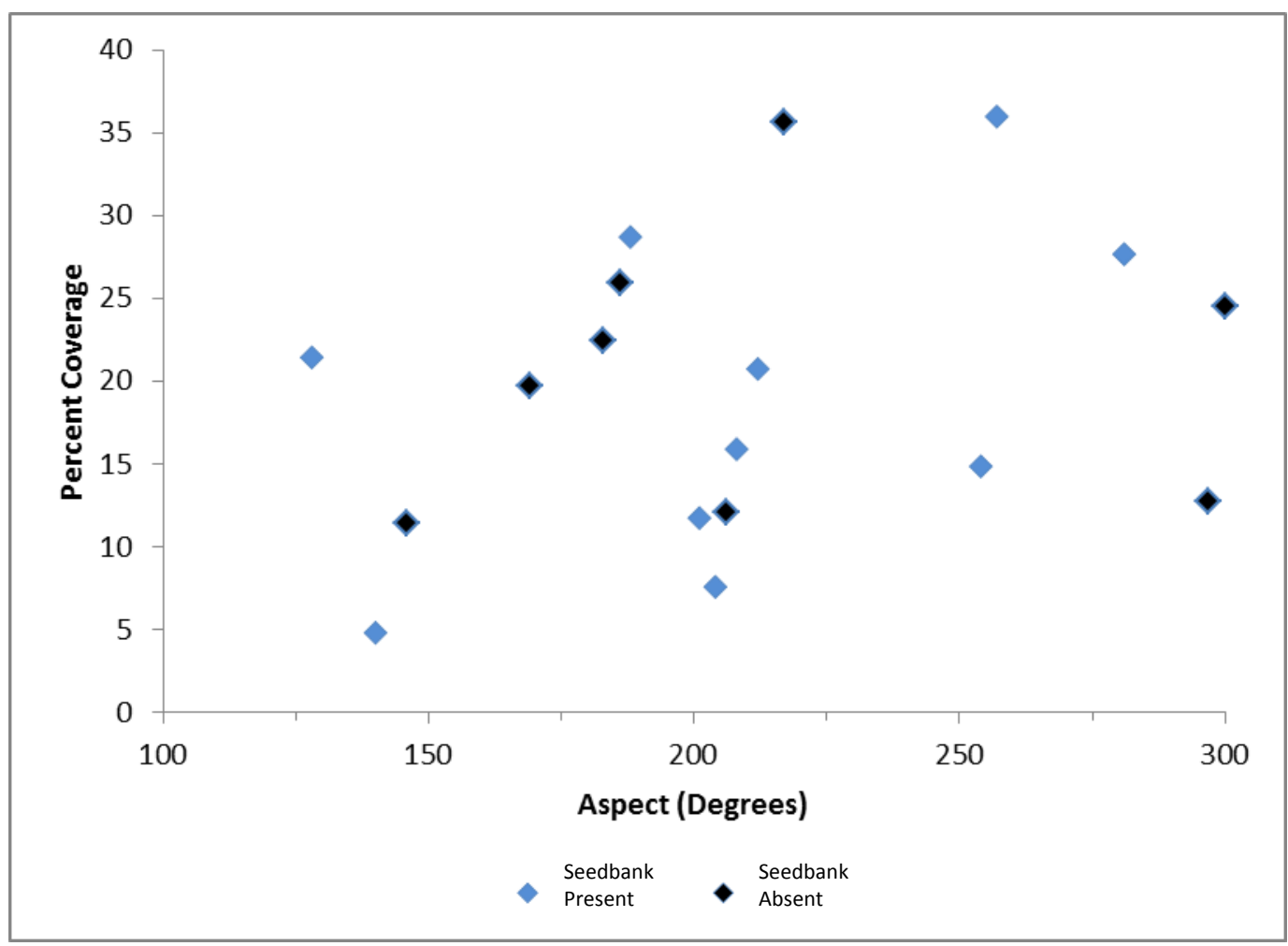

Figure 14: Percent Coverage by Aspect. Percent cover plotted for both treatment types. Blue diamonds represent Seedbank Present plots and black diamonds represent Seedbank Absent plots.

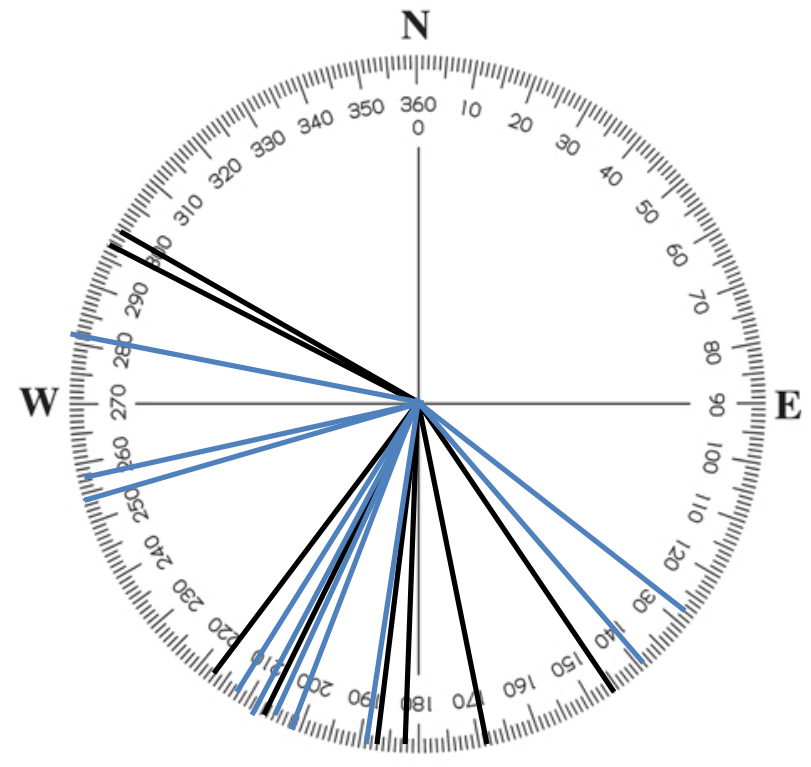

$\mathbf{S}$

Figure 15: Aspect of Plots. Range of aspects for all plots, Seedbank Present and Seedbank Absent. Blue lines represent Seedbank Present plots and black lines represent Seedbank Absent plots. 


\subsection{Discussion}

Two treatments were established to help understand the behavior of E. calycina and its successful invasion of the Guadalupe Nipomo Dunes Complex. Removing the seedbank did not prove to be a significant variable. Both treatment types, the seedbank present (both seedbank and windblown seeds) and absent (only windblown seeds) behaved similarly in their percent coverage of E. calycina but not over time. Seedbank Present plots were able to establish first and had higher coverage rates through the winter. When the seedbank seed source is present it may provide an ecological advantage over areas that only have windblown seed because of early and rapid establishment of cover. This can have significant implications for competition when resources such as moisture and light will become limiting in these ecosystems. Based on the data, windblown seed is a significant contributor to species spread and establishment but a seedbank may contribute to reestablishment when the parent plants have been removed for reason such as by grazing, fire, and windblown sand disturbance. The elements of slope and aspect can also aid in our understanding of these findings.

The slope and aspect in relation to the percent coverage were also not significant indicators of persistence of E. calycina but are still very useful for increasing our knowledge of the habitats of this species. All of the chosen plots had over $30 \%$ coverage of E. calycina and were only located on south and southwest facing aspects. These aspects have less moisture, more intense sunlight and less protection from the coastal winds. Those elements play to the physiological strengths of E. calycina and allow it to outcompete native species. North and northwest aspects are more protected from wind, 
heat and disturbance and thus natives are able to compete with more success. The slope varied considerably and yet E. calycina was equally successful across the range of slopes suggesting slope is not a major affecter of establishment and growth.

From this experiment, we can conclude that the seedbank is not the variable controlling the successful invasion of E. calycina. It appears north and northeast facing aspects are more tolerant to invasion which can be contributed to the amiable conditions on those aspects. It is possible that seeds are released from the seedbank by the strong winds and general disturbance typical of the coastal dune ecosystem. This could bring seeds to the surface of the sand to germinate. It is also possible the sheer number seed created each year by an individual is the primary reason for its success. Each individual creates hundreds of seeds each year. It is unknown the exact number or viability of the seed along the California coast. Australian experiments suggest germination rate is high (7990\%) (Rossiter, 1947; Smith et al., 1999). Initial experimental investigations suggest the viability is significantly lower with seed collected in the GNDC (ranging from 10-25\%) (Steinmaus and Whitaker, Unpublished, 2016).

Every invasive species is successful for different set of characteristics, which makes it difficult when managing those species in natural ecosystems. While many species share growth characteristics and habitat needs, each invasive species is unique. The intent of this research was to expand the knowledge of how E. calycina is successful in invading the California coastal habitats. We now know the buried seedbank is not the primary contributor to overall establishment and coverage of open soil. Windblown seeds are the 
major contributor the success of E. calycina but early establishment in considerably enhanced by the presence of a seedbank. A management focus of E. calycina should be on the current crop of seeds. The seeds on the surface of the sand are the most likely to continue the transformation of coastal dune habitats into monotypic cover of E. calycina. Germination experiments in Australia also support that seeds are much more likely to germinate on the surface (69\%) rather than buried in the sand (Rossiter, 1947; Smith et al., 1999).

This research also suggests that the slope range observed here does not significantly impact E. calycina success. The plots chosen for this study varied widely in slope and no correlation was found for a preferred slope or a slope that would inhibit establishment. It does suggest that E. calycina is not found on north and northeast facing aspects which is supported by anecdotal evidence. Management of E. calycina is better focused on northern facing aspects as they are more naturally defended. North facing aspects have been observed to have a higher density of native species and the presence of mosses and cryptogrammic keep the soil stable and protect it from disturbance. The minimal disturbance paired with less intense hear is critical in preserving the native diversity of species found on north facing aspects. With better conditions (more moisture, less disturbance, increased soil coverage), native species are able to outcompete E. calycina.

There is still a great deal to learn about E. calycina and its ability to successfully invade the California's coastal dunes. This research hopes to inspire further research into additional variables and characteristics of $E$. calycina that might be selecting for success 
in this ecosystem. Important knowledge should be acquired on the competitive interaction of E. calycina and native species. Longer term monitoring of current plots would quantify how quickly E. calycina is invading areas. Those interactions will better inform management about what the future of the complex will look like and how quickly threats are to native biodiversity. 


\section{REFERENCES}

Airamé, S., Dugan, J., Lafferty, K. D., Leslie, H., McArdle, D., \& Warner, R. (2003). Applying ecological criteria to marine reserve design: a case study from the California Channel Islands. Ecological Applications, 13(1), 170-184. http://doi.org/10.1890/1051-0761(2003)013[0170:aectmr]2.0.co;2

Alpert, P. (2000). Invasiveness, invasibility and role of environmental stress in the spread of non-native plants. Perspectives in Plant Ecology, Evolution and Systematics, 3(1), $52-66$.

Ball, I. R., Possingham, H. P., \& Watts, M. E. (2009). Marxan and Relatives: Software for Spatial Conservation Prioritization. Spatial Conservation Prioritization: Quantitative Methods and Computational Tools., 185-195. Retrieved from https://www.google.co.za/search?q=marxan+and+relatives\&oq=marxan + and + relati ves\&aqs $=$ chrome..69i57.4975j0j4\&sourceid $=$ chrome\&es_sm=93\&ie $=\mathrm{UTF}-8$

Baosc. (2012). The Conservation Lands Network. Http://Www.Bayarealands.Org. Retrieved from http://www.bayarealands.org

Bazzaz, F. A. (1991). HABITAT SELECTION IN PLANTS. American Naturalist, 137, S116-S130. Retrieved from $<$ Go to ISI $>$ :/A1991GB85100007

Byers, J. E., Reichard, S., Randall, J. M., Parker, I. M., Carey, S., Lonsdale, W. M., ... Hayes, D. (2002). Directing Research to Reduce the Impacts of Nonindigenous Species. Conservation Biology, 16(3), 630-640.

California Department and Fish Game. (1976). The Natural Resources of the Nipomo Dunes and Wetlands.

California Invasive Plant Council. (2006). California Invasvie Plant Inventory. Retrieved 
from www.cal-ipc.org

Cardinale, B., Duffy, J., \& Gonzalez, A. (2012). Biodiversity loss and its impact on humanity. Nature, 486(7401), 59-67. http://doi.org/10.1038/nature11148

CESA. (2015). California Endangered Species Act. Retrieved from https://www.wildlife.ca.gov/Conservation/CESA

Cowling, R. M., Pressey, R. L., Rouget, M., \& Lombard, A. T. (2003). A conservation plan for a global biodiversity hotspot - The Cape Floristic Region, South Africa. Biological Conservation. http://doi.org/10.1016/S0006-3207(02)00425-1

D’Antonio, C. M., \& Vitousek, P. M. (1992). Biological Invasions by Exotic Grasses, the Grass/Fire Cycle, and Global Change. Annual Review of Ecology and Systematics. http://doi.org/10.1146/annurev.es.23.110192.000431

Daehler, C. C., \& Strong, D. R. (1994). Variable reproductive output among clones of Spartina alterniflora (Poaceae) invading San Francisco Bay, California: The influence of herbivory, pollination, and estab- lishment site. American Journal of Botany, 81(3), 307-313.

Delavenne, J., Metcalfe, K., Smith, R. J., Vaz, S., Martin, C. S., Dupuis, L., ... Carpentier, A. (2012). Systematic conservation planning in the eastern English Channel: Comparing the Marxan and Zonation decision-support tools. ICES Journal of Marine Science. http://doi.org/10.1093/icesjms/fsr180

Di Castri, F. (1989). History of biological invasions with special emphasis on the Old World. Biological Invasions: A Global Perspective, 1-30.

Ehrenfeld, J. G. (2003). Effects of Exotic Plant Invasions on Soil Nutrient Cycling Processes. Ecosystems, 6(6), 503-523. http://doi.org/10.1007/s10021-002-0151-3 
Fenner, M., \& Thompson, K. (2004). The Ecology of Seeds. Cambridge University Press.

Fernandes, L., Day, J., Lewis, A., Slegers, S., Kerrigan, B., Breen, D., ... Stapleton, K. (2005). Establishing representative no-take areas in the great barrier reef: Largescale implementation of theory on marine protected areas. Conservation Biology, 19(6), 1733-1744. http://doi.org/10.1111/j.1523-1739.2005.00302.x

Fiedler, P. L. (1986). Concepts of Rarity in Vascular Plant Species, with Special Reference to the Genus Calochortus Pursh (Liliaceae). Taxon, 35(3), 502-518. http://doi.org/10.2307/1221904

Fisher, J. L., Loneragan, W. A., Dixon, K., \& Veneklaas, E. J. (2009). Soil seed bank compositional change constrains biodiversity in an invaded species-rich woodland. Biological Conservation, 142(2), 256-269. http://doi.org/10.1016/j.biocon.2008.10.019

Franklin, J. F. (1993). Preserving Biodiversity: Species, Ecosystem of Landscape? Ecological Applications, 3(2), 202-205.

Game, E. T., Grantham, H. S., Klein, C., Nicolson, D., Watts, M., Decision, A. E., ... Columbia, B. (2008). Marxan User Manual: For Marxan. Analysis, 1-127.

Gilbertson, D. D., Schwenninger, J.-L., Kemp, R. A., \& Rhodes, E. J. (1999). Sand-drift and Soil Formation Along an Exposed North Atlantic Coastline: 14,000 Years of Diverse Geomorphological, Climatic and Human Impacts. Journal of Archaeological Science, 26, 439-469. Retrieved from http://www.idealibrary.com Gordon, D. R. (1998). Effects of invasive, non-indigenous plant species on ecosystem processes: lessons from Florida. Ecological Applications, 8(4), 975-989.

Groves, C. R., Jensen, D. B., Valutis, L. L., Redford, K. H., Shaffer, M. L., Scott, J. M., 
... Anderson, M. G. (2002). Planning for Biodiversity Conservation: Putting Conservation Science into Practice. BioScience, 52(6), 499. http://doi.org/10.1641/0006-3568(2002)052[0499:PFBCPC]2.0.CO;2

Harte, J. (2001). Land Use, Biodiversity, and the Ecosystem Integrity: The Challenge of Preserving Earth's Life Support System. Ecology Law Quarterly, 27, 929-965.

Hilton-Taylor, C. (2000). The 2000 IUCN Red List of Threatened Species.

Holland, V. L., Keil, D., \& Oyler, L. D. (1995). Botanical Survey and Management of the Nipomo Dunes.

Holmes, P. M. (2002). Depth distribution and compostion of seed banks alien-invaded and uninvaded fynbos vegetation. Austral Ecology, 27 L1 - , 110-120. http://doi.org/10.1046/j.1442-9993.2002.01164.x

Hoyle, J. A., Yelverton, F. H., \& Gannon, T. W. (2013). Evaluating Multiple Rating Methods Utilized in Turfgrass Weed Science. Weed Technology, 27(2), 362-368. Retrieved from http://dx.doi.org/10.1614/WT-D-12-00126.1

Inderjit. (2005). Plant invasions: Habitat invasibility and dominance of invasive plant species. Plant and Soil.

IUCN. (2015). The IUCN Red List of Threatened Species. Retrieved from http://www.iucnredlist.org/

Kremen, C., Cameron, A., Moilanen, A., Phillips, S. J., Thomas, C. D., Beentje, H., ... Zjhra, M. L. (2008). Aligning conservation priorities across taxa in Madagascar with high-resolution planning tools. Science, 320(5873), 222-226. http://doi.org/10.1126/science.1155193

Lamson-Scribner, F. (1895). Grasses as sand and soil binders. US Government Printing 
Office.

Lehtomäki, J., \& Moilanen, A. (2013). Methods and workflow for spatial conservation prioritization using Zonation. Environmental Modelling and Software. http://doi.org/10.1016/j.envsoft.2013.05.001

Liao, C., Peng, R., Luo, Y., Zhou, X., Wu, X., Fang, C., ... Li, B. (2008). Altered ecosysetm carbon and nitrogen cycles by plant invasion: a meta-analysis. New Phytologist, 177(2004), 706-714.

Loreau, M. (2008). Biodiversity and Ecosystem Functioning : Current Knowledge and Future Challenges. Science, 804(2001), 804-809. http://doi.org/10.1126/science.1064088

Love, R. M. (1963, October). Mission veldtgrass. California Agriculture, 1-3.

Lu, Z., Zhi-yun, O., Wei-hua, X., \& Chun-quan, Z. (2014). Determination of priority nature conservation areas and human disturbances in the Yangtze River Basin, China. Journal for Nature Conservation, 22(4), 326-336. http://doi.org/10.1016/j.jnc.2014.02.007

Mack, R. N., Simberloff, D., Lonsdale, W. M., Evans, H., Clout, M., \& Bazzaz, F. A. (2000). Biotic invasions: causes, epidemiology, global consquences and control. Ecological Applications, 10(3), 689-710. http://doi.org/10.1890/00129623(2005)86[249b:IIE]2.0.CO;2

Margules, C. R., \& Pressey, R. L. (2000). A framework for systematic conservation planning, 405(May), 243-253.

Margules, C., \& Sarkar, S. (2007). Systematic Conservation Planning. Cambridge, UK: Cambridge University Press. 
Maron, J. L., \& Marler, M. (2008). Field-based competitive impacts between invaders and natives at varying resource supply. Journal of Ecology, 96(6), 1187-1197. http://doi.org/10.1111/j.1365-2745.2008.01440.x

Mcdonnell, M. D., Possingham, H. P., Ball, I. R., \& Cousins, E. A. (2002). Mathematical methods for spatially cohesive reserve design. Environmental Modeling and Assessment, 7, 107-114.

McKinney, M. L., \& Lockwood, J. L. (1999). Biotic homogenization: A few winners replacing many losers in the next mass extinction. Trends in Ecology and Evolution, 14(11), 450-453. http://doi.org/10.1016/S0169-5347(99)01679-1

Moilanen, A., Pouzols, D., Meller, L., Arponen, A., Leppanen, J., \& Kujala, H. (2014). Zonation: Version 4 User Manual.

Moilanen, A., \& Wintle, B. A. (2007). The boundary-quality penalty: A quantitative method for approximating species responses to fragmentation in reserve selection. Conservation Biology, 21(2), 355-364. http://doi.org/10.1111/j.15231739.2006.00625.x

Myers, N., Mittermeier², R. A., Mittermeier ${ }^{2}$, C. G., Da Fonseca ${ }^{3}$, G. A. B., \& Kent, J. (2000). Biodiversity hotspots for conservation priorities. NATURE Www.nature.com, 403(24).

Olson, D. M., \& Dinerstein, E. (1998). The Global 200: A Representation Approach to Conserving the Earth's Most Biologically Valuable Ecoregions. Conservation Biology, 12(3), 502-515. http://doi.org/10.1046/j.1523-1739.1998.012003502.x

Pickart, A. J. (1997). Control of European Beachgrass (Ammophila arenaria) on the West Coast of the United States. California Exotic Pest Plant Council Symposium 


\section{Proceedings.}

Pimentel, D., Lach, L., Zuniga, R., \& Morrison, D. (2000). Environmental and Economic Costs of Nonindigenous Species in the United States. BioScience, 50(1), 53-65.

Pimm, S. L., Russell, G. J., Gittleman, J. L., \& Brooks, T. M. (1995). The Future of Biodiversity. Science. Retrieved from http://www.ncbi.nlm.nih.gov/pubmed/17841251

Pressey, R. L., Cowling, R. M., \& Rouget, M. (2003). Formulating conservation targets for biodiversity pattern and process in the Cape Floristic Region, South Africa. Biological Conservation. http://doi.org/10.1016/S0006-3207(02)00424-X

Pyšek, P., \& Richardson, D. M. (2010). Pyšek,. Annual Review of Environment and Resources, 35, 25-55. http://doi.org/10.1146/annurev-environ-033009-095548

Rejmánek, M. (2000). Invasive plants: approaches and predictions. Austral Ecology, 25(5), 497-506. http://doi.org/10.1046/j.1442-9993.2000.01080.x

Rodrigues, A. S. L., \& Brooks, T. M. (2007). Shortcuts for Biodiversity Conservation Planning: The Effectiveness of Surrogates. Annual Review of Ecology, Evolution, and Systematics, 38(1), 713-737.

Rossiter, R. C. (1947). Studies on Perennial Veldt Grass.

Rout, M. E., \& Callaway, R. M. (2009). An invasive plant paradox. Science Magazine, 324(May), 734-735. http://doi.org/10.1017/CBO9781107415324.004

Sakai, A. K., Allendorf, F. W., Holt, J. S., Lodge, D. M., Molofsky, J., With, K. A., ... Weller, S. G. (2016). The Population Biology of Invasive Specie. Annual Review of Ecology and Systematics, 32(2001), 305-332.

Smith, M. A., Bell, D. T., \& Loneragan, W. A. (1999). Comparative seed germination 
ecology of Austrostipa compressa and Ehrharta calycina (Poaceae) in a Western Australian Banksia woodland. Australian Journal of Ecology, 24(1), 35-42. http://doi.org/10.1046/j.1442-9993.1999.00944.x

Stewart, R. R., \& Possingham, H. P. (2005). Efficiency, costs and trade-offs in marine reserve system design. Environmental Modeling and Assessment, 10(3), 203-213. http://doi.org/10.1007/s10666-005-9001-y

The Land Conservatory of San Luis Obispo County. (2003). The Dunes GIS Project: Setting Priorities for Restoration. Unpublished.

The Land Conservatory of San Luis Obispo County. (2011). Meeting Minutes: Restoration Task Force Retreat. Unpublished.

Thompson, J. D. (1991). The Biology of an Invasive Plant - What Makes SpartinaAnglica So Successful. Bioscience, 41(6), 393-401. http://doi.org/10.2307/1311746

U.S. Fish and Wildlife Service. (2000). Proposed Guadalupe-Nipomo National Wildlife Refuge.

Vandenberg AFB. (1996). Final Report of the successful creation of wetlands and restoration of uplands at San Antonio Terrace Vandenberg AFB, California.

Verboom, G. A., Linder, H. P., \& Stock, W. D. (2004). T ESTING THE ADAPTIVE NATURE OF RADIATION : A FRICAN GRASS GENUS E HRHARTA 1 ( P OACEAE : E HRHARTOIDEAE ). American Journal of Botany, 91(9), 1364-1370.

Verboom, G. A., Moore, T. E., Hoffmann, V., \& Cramer, M. D. (2012). The roles of climate and soil nutrients in shaping the life histories of grasses native to the Cape Floristic Region. Plant and Soil, 355(1-2), 323-340. http://doi.org/10.1007/s11104$011-1102-6$ 
Vila, M., \& Weiner, J. (2004). Are invasive plant species better competitors than native plant species?: evidence from pair-wise experiments. Oikos, 105(2), 229-238.

Ward, T. J., Vanderklift, M. A., Nicholls, A. O., \& Kenchington, R. A. (1999). Selecting marine reserves using habitats and species assemblages as surrogates for biological diversity. Ecological Applications. http://doi.org/10.1890/10510761(1999)009[0691:SMRUHA]2.0.CO;2

Wilcove, D. S., Rothstein, D., Dubow, J., Phillips, A., \& Losos, E. (1998). Quantifying threats to imperiled species in the United States. Assessing the relative importance of habitat destruction, alien species, pollution, overexploitation, and disease. BioScience, 48(18), 607-615. http://doi.org/10.2307/1313420

Williamson, M., \& Fitter, A. (1996). The Varying Success of Invaders. Ecology, 77(6), $1661-1666$.

Wilson, J. B., Rapson, G. L., Sykes, M. T., Watkins, A. J., \& Williams, P. A. (1992). Distributions and Climatic Correlations of Some Exotic Species Along Roadsides in South Island, New Zealand. Journal of Biogeography, 19(2), 183-193.

Wintle, B. A. (2008). A review of biodiversity investment prioritization tools. A report to the Biodiversity Expert Working Group toward the development of the Investment Framework for Environmental Resources. 


\section{APPENDICES}

\section{APPENDIX A: WORKING GROUP PARTICIPANTS}

\begin{tabular}{|c|c|c|}
\hline Working Group & Participant & Affiliation \\
\hline \multicolumn{3}{|l|}{ Flora } \\
\hline & Lauren Brown, Botanist & $\begin{array}{l}\text { California Native Plant Society, } \\
\text { San Luis Obispo }\end{array}$ \\
\hline & John Chesnut, Botanist & $\begin{array}{l}\text { California Native Plant Society, } \\
\text { San Luis Obispo }\end{array}$ \\
\hline & Steve Junack, Botanist & Santa Barbara Botanical Garden \\
\hline & Alyssa Berry, Biologist & $\begin{array}{l}\text { Padres Inc., Chevron Mitigation } \\
\text { Project }\end{array}$ \\
\hline & Jennifer Langford, Biologist & $\begin{array}{l}\text { Padres Inc., Chevron Mitigation } \\
\text { Project }\end{array}$ \\
\hline \multicolumn{3}{|l|}{ Mammals } \\
\hline & Stephanie Little, Biologist & California State Parks, Oceano \\
\hline & $\begin{array}{l}\text { Dr. Francis Villablanca, } \\
\text { Biology Professor }\end{array}$ & $\begin{array}{l}\text { Cal Poly State University, San } \\
\text { Luis Obispo }\end{array}$ \\
\hline & $\begin{array}{l}\text { Julianna Trunzo, Biology } \\
\text { Instructor }\end{array}$ & $\begin{array}{l}\text { Cal Poly State University, San } \\
\text { Luis Obispo }\end{array}$ \\
\hline \multicolumn{3}{|l|}{ Birds } \\
\hline & Tom Edell, Biologist & Cal Trans, Retired \\
\hline & Jodi Isaacs, Biologist & California State Parks, Oceano \\
\hline & Stephanie Little, Biologist & California State Parks, Oceano \\
\hline & Brad Schram, Birder & Audobon Society \\
\hline & Jessica Griffiths, Biologist & Althouse \& Mead, Inc \\
\hline \multicolumn{3}{|l|}{ Reptiles and Amphibians } \\
\hline & $\begin{array}{l}\text { Dr. Sam Sweet, Biology } \\
\text { Professor }\end{array}$ & $\begin{array}{l}\text { University of California, Santa } \\
\text { Barbara }\end{array}$ \\
\hline & Julius Frazier, Instructor & $\begin{array}{l}\text { Cal Poly State University, San } \\
\text { Luis Obispo }\end{array}$ \\
\hline \multicolumn{3}{|l|}{ Invertebrates } \\
\hline & Dr. Denise Knapp, Biologist & Santa Barbara Botanical Garden \\
\hline & $\begin{array}{l}\text { Dr. Larisa Vredevoe, Biology } \\
\text { Professor }\end{array}$ & $\begin{array}{l}\text { Cal Poly State University, San } \\
\text { Luis Obispo }\end{array}$ \\
\hline & $\begin{array}{l}\text { Dr. Francis Villablanca, } \\
\text { Biology Professor }\end{array}$ & $\begin{array}{l}\text { Cal Poly State University, San } \\
\text { Luis Obispo }\end{array}$ \\
\hline \multicolumn{3}{|l|}{ Lichens } \\
\hline & $\begin{array}{l}\text { Kerry Knudsen, } \\
\text { Lichenologist }\end{array}$ & Prague University \\
\hline & Lisa Andreano, Biologist & California State Parks \\
\hline & Michael Walgren, Biologist & California State Parks \\
\hline
\end{tabular}




\section{APPENDIX B: FINE FILTER SPECIES}

\begin{tabular}{|c|c|c|}
\hline Common Name & Scientific Name & $\begin{array}{l}\text { Percent of } \\
\text { Habitat } \\
\text { Conserved }\end{array}$ \\
\hline \multicolumn{3}{|l|}{ Flora } \\
\hline Beach Sand Verbena & Abronia maritima & $45 \%$ \\
\hline La Graciosa Thistle & Cirsium loncholepis & $45 \%$ \\
\hline Surf Thistle & Cirsium rhothophilum & $45 \%$ \\
\hline Dune Larkspur & Delphinium parri var. blochmaniae & $45 \%$ \\
\hline Beach Spectacle Pod & Dithyrea maritima & $45 \%$ \\
\hline Blochman's Leafy Daisy & Erigeron blochmaniae & $25 \%$ \\
\hline Suffrutescent Wallflower & Erysimum suffrutescens & $35 \%$ \\
\hline Kellogg's Horkelia & Horkelia cuneata ssp. sericea & $35 \%$ \\
\hline California Prickly Phlox & Leptodactylon californicum ssp. tomentosum & $35 \%$ \\
\hline Nipomo Lupine & Lupinus nipomensis & $45 \%$ \\
\hline Giant Coreopsis & Lyptosyne gigantea & $35 \%$ \\
\hline Dunedelion & Malacothrix incana & $35 \%$ \\
\hline Crisp Monardella & Mondarella crispa & $35 \%$ \\
\hline San Luis Obispo Monardella & Mondardella undulata sp. undulata & $45 \%$ \\
\hline California Spineflower & Mucronea californica & $25 \%$ \\
\hline Gambel's Yellowcress & Nasturtium gambelii & $45 \%$ \\
\hline Dune Almond & Prunus fasciculata var. punctata & $45 \%$ \\
\hline Dune Ragwort & Senecio blochmaniae & $25 \%$ \\
\hline Leopold's Rush & Juncus acutus ssp. leopoldii & $45 \%$ \\
\hline Parish's Broomrape & Orobanche parishii ssp.brachyloba & $45 \%$ \\
\hline Blochman's Dudleya & Dudleya blochmaniae ssp. blochmaniae & $45 \%$ \\
\hline Cottonheads & Nemacaulis denudata & $45 \%$ \\
\hline Darkflowered Figwort & Scrophularia atrata & $45 \%$ \\
\hline California Sawgrass & Cladium californicum & $45 \%$ \\
\hline Rocky Mountain Pond-lily & Nuphar polysedala & $45 \%$ \\
\hline Nuttall's Milkvetch & Astragalus nuttallii var. nuttallii & $35 \%$ \\
\hline Mesa Horkelia & Horkelia cuneata ssp. puberula & $35 \%$ \\
\hline Coastal Goosefoot & Chenopodium littoreum & $35 \%$ \\
\hline Culy Leaved Monardella & Monardella sinuata ssp. sinuata & $35 \%$ \\
\hline Hooover's Bentgrass & Agrostis hooveri & $25 \%$ \\
\hline \multicolumn{3}{|l|}{ Birds } \\
\hline Barn swallow & Hirundo rustica & $25 \%$ \\
\hline Pied-billed Grebe & Podilymbus podiceps & $35 \%$ \\
\hline Least Bittern & Ixobrychus exilis & $45 \%$ \\
\hline Northern Harrier & Circus cyaneus & $35 \%$ \\
\hline Virginia Rail & Rallus limicola & $35 \%$ \\
\hline Sora & Porzana carolina & $45 \%$ \\
\hline American Coot & Fulica americana & $25 \%$ \\
\hline
\end{tabular}




\begin{tabular}{|c|c|c|}
\hline Marsh Wren & Cistothorus palustris & $25 \%$ \\
\hline Red-winged Blackbird & Agelaius phoeniceus & $25 \%$ \\
\hline Song Sparrow & Melospiza melodia & $25 \%$ \\
\hline Brown-headed Cowbird & Molothrus ater & $25 \%$ \\
\hline Common Yellowthroat & Geothlypis trichas & $25 \%$ \\
\hline Bushtit & Psaltriparus minimus & $25 \%$ \\
\hline Black-necked Stilt & Himantopus mexicanus & $45 \%$ \\
\hline American Avocet & Recurvirostra americana & $45 \%$ \\
\hline Brewer's Blackbird & Euphagus cyanocephalus & $25 \%$ \\
\hline Blue-gray Gnatcatcher & Polioptila caerulea & $25 \%$ \\
\hline California Quail & Callipepla californica & $25 \%$ \\
\hline BeWick's Wren & Thryomanes bewickii & $25 \%$ \\
\hline Loggerhead Shrike & Lanius ludovicianus & $35 \%$ \\
\hline California Thrasher & Toxostoma redivivum & $25 \%$ \\
\hline White-crowned Sparrow & Zonotrichia leucophrys & $25 \%$ \\
\hline California Towhee & Melozone crissalis & $25 \%$ \\
\hline Wrentit & Chamaea fasciata & $25 \%$ \\
\hline Spotted Towhee & Pipilo maculatus & $25 \%$ \\
\hline Warbling Vireo & Vireo gilvus & $45 \%$ \\
\hline Copper's Hawk & Accipiter cooperii & $35 \%$ \\
\hline Nuttall's Woodpecker & Picoides nuttallii & $25 \%$ \\
\hline Downy Woodpecker & Picoides pubescens & $25 \%$ \\
\hline Northern Flicker & Colaptes auratus & $25 \%$ \\
\hline American Krestel & Falco sparverius & $35 \%$ \\
\hline Hutton's Vireo & Vireo huttoni & $35 \%$ \\
\hline Tree Swallow & Tachycineta bicolor & $35 \%$ \\
\hline Swainson's Thrush & Catharus ustulatus & $25 \%$ \\
\hline American Robin & Turdus migratorius & $25 \%$ \\
\hline Wilson's Warbler & Wilsonia pusilla & $25 \%$ \\
\hline Purple Finch & Carpodacus purpureus & $35 \%$ \\
\hline Lesser Goldfinch & Carduelis psaltria & $25 \%$ \\
\hline Mourning Dove & Zenaida macroura & $25 \%$ \\
\hline Pacific Slope Flycatcher & Empidonax difficilis & $25 \%$ \\
\hline American Crow & Corvus brachyrhynchos & $35 \%$ \\
\hline Red Tailed Hawk & Buteo jamaicensis & $35 \%$ \\
\hline Great Horned Owl & Bubo virginianus & $35 \%$ \\
\hline Allen's Hummingbird & Selasphorus sasin & $25 \%$ \\
\hline Anna's Hummingbird & Calypte anna & $25 \%$ \\
\hline Western Scrub Jay & Aphelocoma californica & $25 \%$ \\
\hline Orange Crowned Warbler & Vermivora celata & $25 \%$ \\
\hline Yellow Warbler & Dendroica petechia & $25 \%$ \\
\hline
\end{tabular}




\begin{tabular}{|l|l|c|}
\hline Chestnut Backed Chickadee & Poecile rufescens & $25 \%$ \\
\hline American Goldfinch & Carduelis tristis & $25 \%$ \\
\hline Semipalmated Plover & Charadrius semipalmatus & $45 \%$ \\
\hline Horned Lark & Eremophila alpestris & $35 \%$ \\
\hline California Least Tern & Sternula antillarum browni & $25 \%$ \\
\hline Western Snowy Plover & Charadrius alexandrinus nivosus & $25 \%$ \\
\hline Kill Deer & Charadrius vociferus & $25 \%$ \\
\hline Black Phoebe & Sayornis nigricans & $35 \%$ \\
\hline Cliff Swallow & Petrochelidon pyrrhonota & $35 \%$ \\
\hline Ruddy Duck & Oxyura jamaicensis & $25 \%$ \\
\hline House Finch & Carpodacus mexicanus & $25 \%$ \\
\hline Cassin's Kingbird & Tyrannus vociferans & $45 \%$ \\
\hline Dark Eyed Junco & Junco hyemalis & $35 \%$ \\
\hline Black-crowned Night Heron & Nycticorax nycticorax & $45 \%$ \\
\hline Gadwall & Anas strepera & $25 \%$ \\
\hline Mallard & Anas platyrhynchos & $25 \%$ \\
\hline Cinnamon Teal & Anas cyanoptera & $35 \%$ \\
\hline Reptiles and Amphibians & \multicolumn{2}{|l|}{} \\
\hline Western Pond Turtle & Actinemys marmorata & $35 \%$ \\
\hline Northern California Legless Lizard & Anniella pulchra & $35 \%$ \\
\hline Two-striped Garter Snake & Thamnophis hammondii & $35 \%$ \\
\hline California Red-legged Frog & Rana draytonii & $45 \%$ \\
\hline California Horned Lizard & Phrynosoma blainvillii & $35 \%$ \\
\hline Mammals & Lasiurus blossevillii & \\
\hline Red Bat & Taxidea taxus & \\
\hline American Badger & \\
\hline
\end{tabular}

